Summer 7-21-2021

\title{
Wound Care Management and Documentation Non-Compliance in Prevention and Care of Wounds
}

\section{Tobechukwu Unaegbu}

University of St. Augustine for Health Sciences, t.unaegbu@usa.edu

DOI: https://doi.org/10.46409/sr.XPUU8046

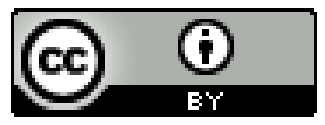

This work is licensed under a Creative Commons Attribution 4.0 License.

Follow this and additional works at: https://soar.usa.edu/scholprojects

Part of the Education Commons, and the Medicine and Health Sciences Commons

\section{Recommended Citation}

Unaegbu, T. (2021). Wound Care Management and Documentation Non-Compliance in Prevention and Care of Wounds. [Doctoral project, University of St Augustine for Health Sciences]. SOAR @ USA: Student Scholarly Projects Collection. https://doi.org/10.46409/sr.XPUU8046

This Scholarly Project is brought to you for free and open access by the Student Research at SOAR @ USA. It has been accepted for inclusion in Student Scholarly Projects by an authorized administrator of SOAR @ USA. For more information, please contact soar@usa.edu, erobinson@usa.edu. 


\section{Wound Care Management and Documentation Non- Compliance in Prevention and Care of Wounds}

Tobechukwu Unaegbu, MSN, APRN, FNP-BC, FNP-C

School of Nursing, University of St. Augustine for Health Sciences

This Manuscript Partially Fulfills the Requirements for the

Doctor of Nursing Practice Program and is Approved by:

Robin Kirschner, EdD, DNP, RN, CNS

Laynette Goudy-Egger, DNP, FNP-BC, MSN, CWS

July 21, 2021 


\begin{abstract}
The incidence of non-compliance and adherence to best practices wound care competence continues to be an issue among the clinical staff of the Veterans Affairs Medical Center (VA). At the VA, there is a practice problem of non-compliance and adherence to best practices wound care competency as evidenced in the electronic medical record (EMR) documentation among the clinical staff. A PICOT question was developed to explore if the establishment of a staff best practices wound care policy focusing on EMR documentation will improve proper wound care management among the clinical staff. The clinical site is a hospital consisting of 40 acute care beds. A new policy adjusted documentation with the use of the Braden scale and the spinal cord impairment monitoring (SCI-PUMT) tools and documentation in the EMR at appropriate times was implemented. A pretest and posttest were conducted to determine the significance of the total documentation using the Braden or SCI-PUMT tools, total accurate documentation using the wound care tools, and the number of multidisciplinary team contacts using the EMR. The results showed no statistically significant improvement with $t$ $=1.66, \mathrm{p}=.107, \mathrm{t}=1.03, \mathrm{p}=.310$, and $\mathrm{t}=-0.31, \mathrm{p}=.775$, respectively. Although the above results did not show any statistical significance after two months of the project implementation, a re-implementation of the project is recommended with the elimination of the barriers encountered during the project implementation.
\end{abstract}




\section{Wound Care Management and Documentation Non-Compliance in Prevention and Care of Wounds}

Wound care continues to be an issue in the United States (US) health care institutions, including the Veterans Affairs Medical Center (VA) in Detroit, Michigan (Cowan, Garvan, Rugs, Banks, Chavez, \& Orozco, 2018). Due to the complexity and wound types which may be acute or chronic including spinal cord injuries, pressure injuries, surgical wounds, combat wounds, competent wound care management skills by the clinical staff are required to improve and prevention of complications of such wounds (Cowan et al., 2018). According to Cowan et al. (2018), evidence-based wound care among clinicians has been shown to improve wound care management and documentation. Communication of the status of wounds in the electronic medical record (EMR) is essential to ensure a multidisciplinary collaboration of care by standardizing wound care documentation to improve identification of the patients wound status.

Effective policies that direct actions of the clinical staff is important in ensuring they can safely and effectively identify, evaluate, and manage patients' wounds (Bamohammed, Mohidin, George, \& Al-Aidarous, 2018). Improper wound care extends patients' wound healing length, thereby adding additional cost for treatment (Goudy-Egger \& Dunn, 2018). Therefore, a new wound care policy that directs clinical staff in care delivery documentation in the EMR creates alignment between expectations and patient outcomes.

The goal of this evidence-based project was to establish a new wound care policy with a focus on EMR documentation supporting improved identification of patient wound status as an effort to decrease patient wound incidences and improve proper wound management. 


\section{Significance of the Practice Problem}

At the VA, there is a practice problem of non-compliance and adherence to best practices wound care competency as evidenced in the EMR documentation among the clinical staff which contributes to poor wound healing and management. An updated wound care policy was established with a focus on EMR documentation to provide policy adherence supporting best practices for preventing and managing wounds including the most complex wounds and injuries (Cowan et al., 2018). A study conducted by Oseni and Adejumo (2014) showed that continuing wound care education helps improve wound care. The new wound care policy focusing on EMR wound care documentation outlines the expectations required for clinical staff to provide wound care. The importance of staff knowledge, skills, and ability in preventing and improving patient wound care is instrumental in achieving best outcomes. Therefore, clinical staff education aligned with the wound care policy was measured through the EMR documentation.

According to Walker et al. (2019), pressure injuries are the types of wounds that affects 2.5 million people in the U.S., costing $\$ 9.1$ to $\$ 11.6$ billion annually. Although there are other types of wounds, pressure injuries that can be prevented, account for more than 60,000 deaths and 20,000 lawsuits annually (Walker et al., 2019). In the US, almost 8.2 million Medicare beneficiaries have at least one or more types of wounds or wound-related infections, costing Medicare about $\$ 28$ to $\$ 96.8$ billion annually (Driver et al., 2019). Globally, in 2014, wound care cost an average of $\$ 2.8$ billion, and it is projected to increase up to $\$ 3.5$ billion in 2021 (Sen, 2019). Policy compliance documentation will support improved wound care outcomes and decrease organizational costs.

Wounds can be a burden to both the patients and their relatives. According to Driver et al. (2018), untreated or poorly managed wounds can lead to complications such as (a) amputations, 
(b) sepsis, (c) social isolation for some patients, (d) decreased ambulation/mobility, (e) depression, (f) pain, and (g) caregiver burnout for relatives taking care of wound patients. Additionally, veterans from combat with spinal cord injuries are predisposed to pressure injuries, where clinicians lacking knowledge on preventing wounds and managing such patients will create more problems (Johnson-Kunjukutty \& Delille, 2019). Following wound care policy documentation learned through clinical staff attending continuing wound care training assists in preventing, improving, reducing cost, and burnout associated with wound treatment and management (McCluskey \& McCarthy, 2017). Policy-related wound documentation of prevention and wound management is a leadership identified current problem. This lack of policy adherence when corrected will lead to compliance with EMR documentation supporting multidisciplinary collaboration for (a) prevention, reduction of wound complications, (b) an increase proper wound management, and (c) reduction of cost.

\section{PICOT Question}

The PICOT question that guided this project was through clearly identifying the population $(\mathrm{P})$, intervention or implementation $(\mathrm{I})$, comparison to current practice $(\mathrm{C})$, expected outcomes from the intervention or implementation $(\mathrm{O})$, and the time frame of the project $(\mathrm{T})$. The PICOT question for this project is as follows: Among the wound care clinical staff members at the VA (P) will establishment of a staff best practices wound care policy focusing on EMR documentation (I) compared to current staff practices (C) improve multidisciplinary collaboration to decrease wound incidences and improve proper wound care management (O) within two months of initiation of the practice change $(\mathrm{T})$ ?

Population (P): The population that benefited from the project were the patients, supported by the following stakeholders: clinical staff members, including the nursing staff, 
physicians, nurse practitioners, physician assistants, nursing assistants, and the nursing managers. Intervention (I): The intervention was the establishment of the wound care policy with a focus on documentation. The policy was addressed through wound care training protocol and procedures to be documented in the EMR. The policy was adjusted to improve staff compliance. Comparison (C): The new wound care policy was compared to national standard guidelines and documentation expectations. Outcome $(\mathrm{O})$ : Improved documentation of a multidisciplinary collaboration approach to wound care leading to a reduction of the incidence of wounds and improved proper wound management. The data collected was through staff acknowledgement of the new policy and staff documented wound care charting in the EMR. Timing (T): Improvement in the staff compliance in wound care documentation with the two months of the project implementation.

\section{Evidence-Based Practice Framework \& Change Theory}

\section{Evidence-Based Practice Framework}

The Johns Hopkins evidence-based framework guided the development and implementation of the VA evidence-based practice problem change (Dang \& Dearholt, 2017). According to Dang and Dearholt (2017), the Johns Hopkins model involves three steps: practice question, evidence, and translation (PET process).

The first step is the clinical practice question which is, why are there increased incidences of wounds and missing documentation for high-quality care delivery. This clinical practice question the lead to the PICOT question, which is: Among the wound care clinical staff members at the VA (P) will establishment of a staff best practices wound care policy focusing on EMR documentation (I) compared to current staff practices (C) improve multidisciplinary collaboration to decrease wound incidences and improve proper wound care management $(\mathrm{O})$ 
within two months of initiation of the practice change (T)? Identifying the practice question, directed the project (Dang \& Dearholt, 2017).

The next step of the Johns Hopkins model was the use of the best evidence to answer the identified question. For this project, best evidence practices as stated by Cowan et al. (2018) among other researchers, was to identify the clinical issue and solution options aligning with the environment. Lastly, "translation," was the last process that required the utilization of the evidence found applied in practice where change was needed. Concerning the evidence-based practice change at the VA, the evidence found was utilized to reestablish a wound policy focusing on EMR documentation and improve documentation of best practices outlined in the policy to improve clinical staff practice leading to multidisciplinary collaboration to ultimately improve patient outcomes.

\section{Change Theory}

Lewin's change theory (as cited in Batras et al., 2016) served as the foundation for the evidence-based project. Lewin's change theory is a three-phase model that includes "unfreezing," "change," and "refreeze" (Batras, Duff, \& Smith, 2016). The theory uses the three phases in identifying an organizational problem that needs change, implementing the change, and lastly, sustaining the change implemented (Batras et al., 2016).

In the first phase change theory (unfreezing) the practice problem was identified as an increase incidence of wounds due to improper documentation of wound management by the clinical staff compared with best practices of wound care. During this phase, the current VA wound care policy was evaluated. In addition, the staff opinions for the rationale for their noncompliance was assessed. According to Lewin, as individuals are sometimes influenced by group behavior and group norms, the group behaviors and group norms of the clinical staff that do not 
conform with the practice change will be noted, and leadership will plan for correction (Batras et al., 2016). During this phase, the stakeholders were identified and involved in the process.

The second phase of the Lewin change theory is called the "change." At this phase, the proposed change was implemented. The change, which is the implementation of the new wound care policy with a focus on documentation, was implemented through good communication, support, stakeholders' involvement, and use of other measures that enhanced the smooth implementation such as flyers, emails, and so forth. During the implementation phase, feedback from the clinical staff were sought and acknowledged with reinforcement and clarification where needed while monitoring EMR documentation.

The last phase of Lewin's theory of change is the "refreeze" phase. This phase involved sustaining the practice change (Mulholland, 2017). After implementing the policy as the practice change, the change made was anchored into the clinical staff culture. The following were put in place for the sustainability of the implemented change; (a) staff encouragement, (b) sending due dates reminders of wound care updates to the staff, (c) rewards, (d) periodic staff evaluation, and (e) leader expectations via establishment of a periodic documentation audit.

\section{Evidence Search Strategy}

The electronic databases used for the literature search included Cumulative Index to Nursing and Allied Health Literature (CINAHL), PubMed, Medline, Ovid, ProQuest, and ScienceDirect. The following key words were used for the search: Combat Veteran Health Administration, wound management, wound care educational training, wound providers, competence, knowledge, wound healing, multi-professional practice, evidence-based practice, wound care, pressure injury, prevention, and control. Combat (wounded) veterans were noted in some databases used "combat veterans" while some used "wounded veterans," patients with both 
acute and chronic wounds, patients with different stages of wound, inpatient and outpatient veterans with wound, veterans of all ages, sex, and ethnicity were the inclusion criteria. Veterans with only psychological pain not related to wound, self-managed wounds, textbooks were excluded.

Both full text and non-full text, evidence-based journals, peered reviewed articles were included. English was set as the language for the literature search, and the number of years of publication was limited to 5 years (2015-2020). Initially, 30 evidence-based articles were retrieved and 10 evidence-based articles were finally selected after careful review using the exclusion criteria.

\section{Evidence Search Results}

An extensive evidence-based research article search was made using the following databases: Cumulative Index to Nursing and Allied Health Literature (CINAHL), PubMed, Medline, Ovid, ProQuest, and ScienceDirect. The search resulted in 30 research articles as shown in Appendix A: PRISMA Reporting. No additional records were identified through other sources. After duplicates were removed, 23 research articles remained. The 23 research articles were screened, and 10 articles were excluded leaving 13 full-text research articles. Three out of the 13 full research articles were excluded for not meeting the inclusion criteria. Among the excluded research articles were related to veterans with only psychological pain and not woundrelated, self-managed wounds. The final search resulted in 10 research articles. (See Appendix B: Primary Research Results). 
The Johns Hopkins evidence-based practice (EBP) model was used in grading the 10 research articles found for the project. The EBP model by Johns Hopkins is used to evaluate the level and quality of evidence (Dang \& Dearholt, 2017). Appendix B: Primary Research results evidence and Appendix C: Systematic Review studies shows the research articles' grading details. As shown in Appendix B, three (Level II), four (Level III), and two (Level IV) research articles were found using the Johns Hopkins EBP grading model. Among the nine research articles in Appendix B, one (Grade A), four (Grade B), three (Grade A/B), and one (Grade C) articles were found. One systematic review was found as shown in Appendix C where these authors used 27 research studies for their systematic review. The systematic review according to Johns Hopkins EBP model had Level 1 and Grade A evidence. An overview of this material can be seen in Appendix D: Summary of Primary Research Evidence and Appendix E: Summary of Systematic Reviews.

\section{Themes with Practice Recommendations}

A practice problem at the VA is the non-compliance of the clinical staff with current documentation practice expectations related to wound care. The following themes were discovered: continuing education/in-service education, prevention practices, tools for wound care evaluation, and wound care policy will be used to discuss the practice recommendations.

Continuing Education/In-Service Education: Continuing education/in-service education among the clinical staff is vital in the prevention and wound care management. Ousey and Blackburn (2019) indicated that competence and confidence are connected and needed in managing the wound. Ousey and Blackburn (2019) explained that competence acquired through wound care education or training is associated with increased staff confidence in caring for patients with wounds. Awali et al. (2018) studied 200 nurses on the effects of the implementation 
of pressure injury (PI) educational prevention protocol on nurses' knowledge, attitude and practices showed that there is a positive relationship between continuous clinical staff wound care prevention educational program and its effects on pressure injury prevention. Awali et al. (2018) recommend healthcare institutions' development of continuous educational programs that will improve the nurses' knowledge, attitude, and practice related to PI prevention. These studies support that clinical practice education that includes comprehensive documentation improves wound care outcomes.

A cross-sectional, descriptive study by Cowan et al. (2018) found that clinical staff education and documentation were the two areas that the staff lacked regarding wound prevention and management. Oseni and Adejumo (2014) concurred that knowledge of wound documentation and continuing education is essential in improving patients' wound care outcomes. Also, BaMohammed et al. (2018), in their cross-sectional observational study conducted on 41 nurses, concluded that an educational course on wound management for the nurses is essential. These studies support that policy compliance noted in documentation supported through education improves wound prevention.

McCluskey and McCarthy (2017) agree with the importance of clinical staff continuing education. They further explained that when nurses apply the knowledge acquired from the competency training, it significantly enhances patients' outcomes and practice. In the management of patients' chronic wounds, Goudy-Egger and Dunn (2018) in their pretest-posttest research, concluded the need to support the need for continuing education among the clinical staff in the management of patients with a chronic wound. These studies support that educating staff on the wound care policy improves wound care management which can be documented in the EMR. 
Prevention Practices: As the Centers for Medicare and Medicaid (CMS) in 2007 determined that hospital-acquired pressure injuries are preventable, the CMS decided not to pay organizations for pressure injuries that occurred while the patients were in the hospital (Nussbaum et al., 2018). Based on this information, hospitals must implement strategies such as policy and training, that will help prevent wounds. The patients at the VA are prone to developing pressure injuries due to the nature of their wounds, which may lead to immobility and neurological deficit (Awali et al., 2018). In their meta-synthesis, Walker et al. (2020) recommended the importance of clinical staff knowledge in preventing wounds through repositioning, nutrition, and support surfaces. Awali et al. (2018) also noted in their study that strategies such as education of health care staff, implementation of PI guidelines, and appropriate equipment used to reduce PI would make a tremendous difference in preventing PI is among patients. These sources support the establishment of a wound care policy as a means for improving wound care.

Tools for Wound Care Evaluation: The Braden scale and the Spinal Cord Impairment Pressure Ulcer Monitoring (SCI-PUMT) tools are some of the tools that can be used in the evaluation of pressure injury and healing. The Braden scale is a pressure injury risk assessment tool which consists of six subscales: (a) sensory perception, (b) moisture, (c) activity, (d) mobility, (e) nutrition, and (f) friction and shear (Adibelli \& Korkmaz, 2019). Each item is given a score from 1-4, the lower the score, the more the patient is prone to developing pressure injury (Adibelli \& Korkmaz, 2019). According to Adibelli and Korkmaz (2019), the Braden scale is a valid and reliable wound assessment tool with a sensitivity of .95 and specificity of .75 . See Appendix K for the Braden Scale tool. 
Due to the pathophysiological factors involved in individuals with spinal cord injury, the SCI-PUMT was developed (Thomason et al., 2016). The SCI-PUMT includes two subscales; the geometrical factors and the substance factors (Thomason et al., 2016). The geometrical factors measure the surface area, depth, edges, tunneling, and undermining. While the surface factors measure exudate type, necrotic tissue, and amount. When the scores are added, an SCI-PUMT score of 2 means healed wound, and a score of 26 means the most severe wound (Thomason et al., 2016). In research performed by Thomason, Luther, Powell-Cope, Harrow, and Palacio (2014), the SCI-PUMT tool was found to be valid, reliable, and sensitive in detecting pressure injury healing over time in Veterans with spinal cord injury. See Appendix L for the SCI-PUMT.

At the VA (Detroit), the staff are expected to use the tools mentioned above in the assessment, evaluation of wound healing and to document appropriately in the electronic medical records (EMR).

Wound Care Policy: In their cross-sectional research, Soban et al. (2016) recognized that organizational strategies to assist in implementing PI prevention programs might not always work out as intended. The Department of Veterans Affairs Office of Inspector General (OIG), in their audit of 47 V.A. hospitals to evaluate clinicians' compliance with the required PI prevention and management protocols, identified that not all the clinicians adhered to the staff PI prevention as found through documentation (Department of Veterans Affairs Veterans Office of Inspector General, 2015). The OIG recommended that facilities have defined requirements for their PI prevent and management policy or protocol. The establishment of the wound care policy with a focus on EMR documentation aligns with the OIG recommendation.

The OIG, in their recommendation, added that facility managers need to monitor employee compliance and appropriate action instituted where required. With this project, 
establishing a wound care policy with a focus on EMR documentation provided the means to monitor wound care compliance and identify actions for non-compliance.

\section{Setting, Stakeholders, and Systems Change}

\section{Setting}

The project setting was a veterans affairs medical center, which comprises of an inpatient and outpatient units. The inpatient unit consists of 40 acute care beds, 11 intensive care unit beds, and 9 step-down unit beds. This veterans affairs medical center is one of the largest in the United States and provides services to about 350,000 veterans.

\section{Description of a typical participant}

The patients of this facility are typical participants for this project, and the patients are comprised of United States veterans. The patients either have wounds inflicted during combat or a wound acquired as a result of pressure injury. Due to the nature of the wounds acquired during combat, the patients are prone to having complications, while some patients who have other medical issues that are not wound-related develop pressure injuries. The patients at this facility deserve proper wound care management and prevention. As the patients of this facility are the primary focus of this project, the non-compliance of the clinical staff to the wound care best practices and documentation prevents effective management and documentation the patient wounds.

\section{The Organizational Mission and Vision}

The mission of the organization is one that has the veterans' interest at heart in fulfilling President Lincoln's promise "To care for him who shall have borne the battle, and for his widow. And his orphans" by serving and honoring the men and women who are America's veterans 
(U.S. Department of Veterans Affairs, 2015). This project supports the accomplish the organization's mission of caring for the veterans by preventing and managing wounds. The organization's vision is to provide the veterans world-class benefits and services by employing the highest standard of compassion, commitment, excellence, professionalism, integrity, accountability, and stewardship (U.S. Department of Veterans Affairs, 2015).

\section{Organization Need Establishment}

The organizational need was established after discussing and identifying different practice problems with the organization-affiliated preceptor. Increased wound incidences and improper management of patients' wounds due to the non-compliance of the clinical staff to wound care was identified as its most pressing problem. This deficit leads to poor patient outcomes and increased cost for care. Organizational leadership support and will approve the new wound care policy.

\section{The Stakeholders}

The stakeholders included the patients, nurses, nurse practitioners, physicians, physician assistants, certified nursing assistants, unit managers, chief nursing officer, and wound care specialists. Organizational stakeholders represented the multidisciplinary team that collaborated on patient wound care.

\section{The Organizational Support and Project sustainability}

The organizational support was confirmed by introducing the practice change project topic to the stakeholders by the preceptor. Approval for the new wound policy was provided by leadership. As the practice problem has been an ongoing organizational problem, the stakeholders and team members supported in achieving the project's purpose. Staff 
encouragement, rewards, celebrating improvements, updates, feedback with EMR audits, were used for the sustainability of the project.

\section{Required Interprofessional Collaboration}

Multidisciplinary, also called interprofessional collaboration was needed in achieving the purpose of the project. The dietician provided nutrition guidance for the support of wound healing (Awali et al., 2018). The interprofessional collaboration with physical and occupational therapy were needed in mobilizing the patients. Additionally, other stakeholders such as the nurses, nurse practitioners, physicians, physician assistants focused on the care delivery based on documentation to make recommendations to adjust or support current wound care processes.

\section{SWOT Analysis}

The following were the strengths, weaknesses, opportunities, and threats (SWOT) as it related to the project change. The strengths and weaknesses are considered as the internal organizational factors, while the opportunity and threats are the external factors that can influence the project's outcome. The strength of the VA as related to this project included (a) the support of the stakeholders for the practice change, (b) electronic medical record (EMR) availability, which were used in inputting and retrieval of information, and (c) interprofessional staff and clinical staff members availability. The weaknesses were (a) staff time constrain, (b) staff resistance to change, and (c) staff lack of motivation. Identified opportunities were factors that influenced the project, including the federal government's willingness to provide financial support for the practice change project. Lastly, the threats identified that could have negatively affected the project include (a) an uncertain economic environment, (b) a sudden change in the 
national wound care guidelines, and (c) employee turnover. See Appendix F for the SWOT analysis diagram.

\section{Level of system change of the project and the system change.}

The project was supposed to create a meso level of system change. The establishment of the wound care policy required the clinical staff participation in mandatory policy update. Sustaining the wound care policy with focus on EMR documentation was to improve multidisciplinary collaboration leading to the number of patients with wound complications reduced as the clinical staff applies wound care policy.

\section{Implementation Plan with Timeline}

As wound incidences and improper management of wounds is an issue at the VA, the objective of this practice problem change was to improve wound care policy adherence as evidenced by EMR documentation of patients' wound care management and prevention within two months of re-establishing the organization's current wound care policy. The objectives that guided the project's policy creation, implementation, and evaluation were to improve documentation compliance with the policy, prevent patients from developing pressure injury wounds, and support multidisciplinary management of patients' staff, and increased wound care compliance and adherence by the clinical staff.

The current wound care policy was reviewed with an interdisciplinary team of wound care experts with the use of research evidence, clinical guidelines, and VA processes. The project manager who was the lead reviewed and collaboratively adjusted the current policy to become a new wound care policy, adding compliance monitoring. The approval to develop this new policy was confirmed by the current leadership. Upon completion of the new 
collaboratively developed wound care policy, the project manager received final approval from the facility's leadership team for the project implementation. The new policy was focused on the EMR documentation to support multidisciplinary collaboration. Within the new policy was the establishment of regular EMR audit periods where the interdisciplinary team assessed the data to make recommendations for any identified changes in care. Additionally, implementation process for introduction of the new policy to the clinical staff followed the VA processes.

According to the current VA policy, clinical staff are required to identify patients/residents at risk for skin breakdown, prevent avoidable pressure injuries, and chart in the electronic medical record (EMR) (Department of Veterans Affairs Veterans Health Administration, 2019), see Appendix G. The Braden scale and Spinal Cord Impairment Pressure Ulcer Monitoring Tool are two of the tools that clinical staff are required to use in evaluating patients at risk for developing pressure injuries and healing. EMR documentation of these tools by the clinical staff supported their policy compliance.

Introduction of the new wound care policy with a focus on EMR documentation occurred as the clinical staff were expected to attend in-person wound care training and policy updates. The change in staff behavior was measured by their compliance with the policy through the EMR documentation. Attachment of professional evaluation credit to the policy update by the wound care educator served as an incentive to ensure that knowledge was transferred to daily wound care management and documentation.

Through clear and effective communication, the stakeholders' involvement, and feedback from the clinical staff via EMR documentation, the objectives were met. During the implementation and evaluation period, every step was clearly and effectively communicated to the clinical staff and patients who were the primary stakeholders. Any questions from the 
stakeholders were answered. The stakeholders were involved with the progress updates shared throughout the implementation and evaluation periods, which gave them a sense of being part of the project. The stakeholders were encouraged to provide feedback during the implementation and evaluation phases. See Appendix $\mathrm{H}$ for the implementation plan with a timeline.

\section{Budget}

The cost of the project was very minimal. The cost consisted of the hourly wage for the Information Technology (IT) personnel for time spent in educating the program manager on the computer applications and assistance in retrieving data. The project manager was not paid any wage or compensation. The money was spent on purchasing office supplies that were used in printing handouts and posters during the dissemination of the project's period. The financial support from the institution was used wisely to accomplish the project goal. See Appendix I for the budget plan.

\section{EBP and Change Models as Guide to the Recommended Practice Change}

The EBP model used for the project was that of Johns Hopkins evidence-based framework for practice change. The PET steps of the Johns Hopkins evidence-based framework werw used to guide the recommended practice change. The PICOT question for this project was clearly stated as: Among the wound care clinical staff members at the VA (P) will establishment of a staff best practices wound care policy focusing on EMR documentation (I) compared to current staff practices (C) improve multidisciplinary collaboration to decrease wound incidences and improve proper wound care management $(\mathrm{O})$ within two months of initiation of the practice change (T)? With the question as the guide, evidence-based research articles were evaluated and synthesized to answer the PICOT question. The Johns Hopkins evidence-based framework 
guided in grading and leveling of the evidence-based research articles ensuring quality evidencebased articles were selected for the project. With the Johns Hopkins evidence-based framework, one Level 1, three Level 2, four Level 3, and two Level 4 evidence-based research articles were synthesized for this project. Two Grade A, four Grade B, and three Grade A/B research articles were found. During the Johns Hopkins evidence-based frameworks transition phase, the best evidence gathered from the synthesized research articles were selected and used in the implementation of the practice change.

The Lewin's change theory (Mulholland, 2017) was used to manage the change process through three phases: unfreezing, change, and refreezing. At the unfreezing phase of the project, a practice problem was identified as non-compliance with the current wound care policy and EMR documentation. During this phase, (a) the current wound care policy was evaluated and adjusted for establishment, (b) the rationale for the clinical staff non-compliant to the wound care were determined with strategies for compliance, and (c) trends of patients developing pressure injuries because of missed multidisciplinary collaboration evaluation of treatment plans. All the stakeholders were identified and involved during this phase. This phase took one week to gather the needed information.

At the "change" phase, the proposed project change was implemented. The change that was be implemented was the reestablishing the wound care policy-based analysis of the information obtained from the stakeholders. During the implementation phase, good communication, support, and involvement of the stakeholders were employed. Feedback from the stakeholders were acknowledged. PowerPoint presentations, email, staff meetings, and meetings of the stakeholders were used to disseminate information and communicate the change 
implementation's progress. EMR documentation using the two evaluation tools and multidisciplinary collaboration were monitored.

The last phase is the "refreezing," where the implemented change is sustained. After the implementation of the proposed change, it was sustained through (a) staff encouragement, (b) sending due dates reminders of wound care training to the staff, (c) rewards, (d) periodic staff evaluation, successes were celebrated of the improved number of staff attending the wound care training, (f) weekly updates of the staff on the number of pressure injuries, and (g) leadership audits of the EMR documentation. The strategies as mentioned above, were supported by staff engagement while sustaining the practice change. The "change" and the refreezing phases took 7 weeks.

\section{Interprofessional collaboration required during Implementation}

During the implementation phase of the project, interprofessional collaboration commenced. The nurses were charged with wound care documentation using the two wound care tools mentioned earlier. The dietician was consulted to determine nutritionally deficient patients and make sure that those patients were nutritionally stable. The physical therapists and occupational therapists evaluated and mobilize the patients as required. Other professionals involved include the prosthetic department because some patients had pressure injuries related to their prosthetics, and wound care specialists, nurse practitioners, and physicians were given updates on the clinical staff EMR documentation supporting the wound care practice. There were weekly meetings to assess progress and feedback for the project during the implementation phase.

\section{Role of the Project Manager}


As the project manager, the Doctor of Nursing Practice (DNP) student was the person at the helm of the affairs of the project implementation. The project manager coordinated with project team members and ensured the smooth implementation of the project. The project manager who was the director of the project, gathered information, monitored, and ensured smooth project implementation. The leadership skills applied by the project manager for the successful completion of the project were the ability to communicate effectively, listen attentively, and manage time appropriately. The project manager was trustworthy, respectful, and was open to suggestions.

\section{Results}

The project manager was incharge of the project plan. After the problem change intervention implementation, the total documentation using the "Braden scale" or the "spinal cord impairment pressure ulcer monitoring" tools, the total number documented accurately, and the number of multidisciplinary team contacts were evaluated. Clinical staff compliance was measured by the level of completion of the two tools in the EMR. Outcomes improvement of wound care was evaluated by the number of multidisciplinary team encounters (See Appendix J: Data Collection Tools).

Data was collected by the project manager with the assistance of the facility's IT department. Pre-and post-intervention of the clinical staff documentation in the EMR using the= EMR embedded Braden scale and SCIPUM tools were retrieved and analyzed. During the data collection/ retrieval process, HIPAA was observed because only individuals directly involved in the patients' retrieval process was allowed access to the patients' information. During the retrieval, the computer was password protected when not in use. Unidentifiable identification numbers were assigned to the patients. Extra HIPAA protection was also in place because 
patients' information could only be assessed from the facility's computers to protect the patients' information.

A two-tailed independent samples $t$-test was conducted to examine whether the mean of Total_Documentation_using_Braden_or_SCIPUM_tools was significantly different between the Pretest and Posttest categories of Time Period. The result of the two-tailed independent samples $t$-test was not significant based on an alpha value of $0.05, t(31)=1.66, p=.107$, indicating the null hypothesis cannot be rejected. This finding suggests the mean of Total_Documentation_using_Braden_or_SCIPUM_tools was not significantly different between the Pretest and Posttest categories of Time Period. The results are presented in Table 1. A bar plot of the means is presented in Figure 1.

\section{Table 1}

Two-Tailed Independent Samples t-Test for Total_Documentation_using_Braden_or_SCIPUM_tools by Time Period.

\begin{tabular}{|c|c|c|c|c|c|c|c|}
\hline \multirow[b]{2}{*}{ Variable } & \multicolumn{2}{|c|}{ Pretest } & \multicolumn{2}{|c|}{ Posttest } & \multirow[b]{2}{*}{$t$} & \multirow[b]{2}{*}{$p$} & \multirow[b]{2}{*}{$d$} \\
\hline & $M$ & $S D$ & $M$ & $S D$ & & & \\
\hline Total_Documentation_using_Braden_or_SCIPUM_tools & 31.50 & 11.25 & 23.57 & 14.13 & 1.66 & .107 & 0.62 \\
\hline
\end{tabular}

\section{Figure 1}

The mean of Total_Documentation_using_Braden_or_SCIPUM_tools by levels of Time Period. 


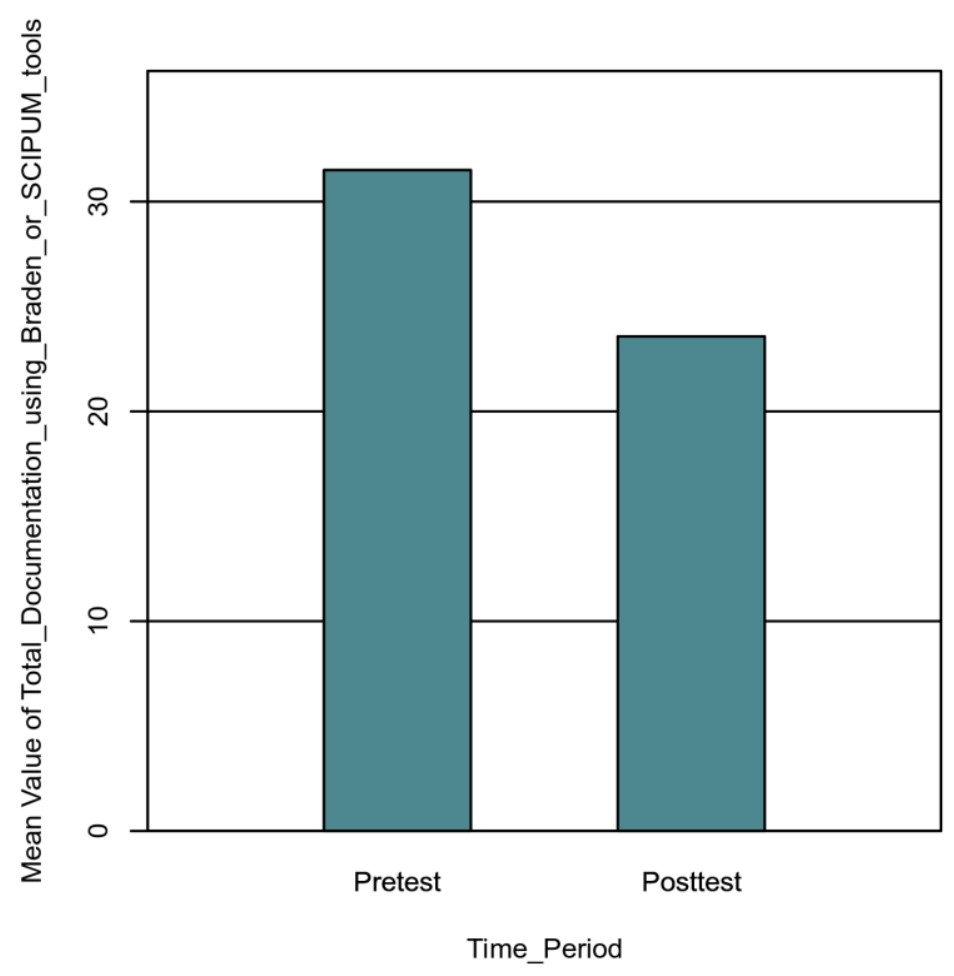

A two-tailed independent samples $t$-test was conducted to examine whether the mean of Total_Documentation_accurately_using_tools was significantly different between the Pretest and Posttest categories of Time Period.

The result of the two-tailed independent samples $t$-test was not significant based on an alpha value of $0.05, t(31)=1.03, p=.310$, indicating the null hypothesis cannot be rejected. This finding suggests the mean of Total_Documentation_accurately_using_tools was not significantly different between the Pretest and Posttest categories of Time_Period. The results are presented in Table 3. A bar plot of the means is presented in Figure 3.

\section{Table 3}

Two-Tailed Independent Samples t-Test for Total_Documentation_accurately_using_tools by Time_Period

Pretest Posttest

Variable

$\begin{array}{lllllll}M & S D & M & S D & t & p & d\end{array}$




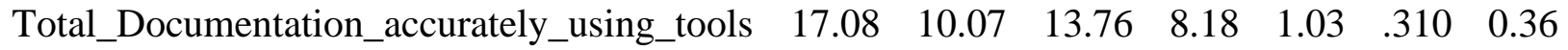
Note. $\mathrm{N}=33$. Degrees of Freedom for the $t$-statistic $=31 . d$ represents Cohen's $d$.

Figure 3

The mean of Total_Documentation_accurately_using_tools by levels of Time_Period

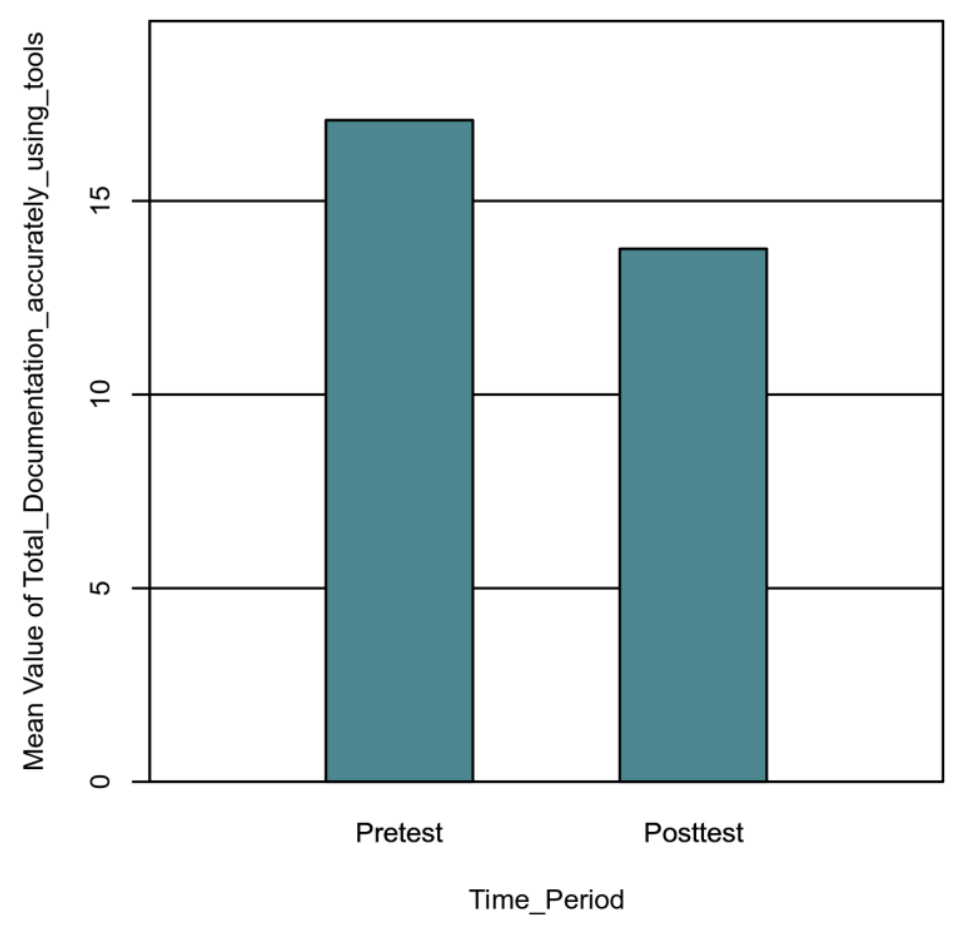

Lastly, a two-tailed independent samples $t$-test was conducted to examine whether the mean of Number_of_Multidisplinary_team_contacts was significantly different between the Pretest and Posttest categories of Time Period. The result of the two-tailed independent samples $t$-test was not significant based on an alpha value of $0.05, t(31)=-0.31, p=.755$, indicating the null hypothesis cannot be rejected. This finding suggests the mean of Number_of_Multidisplinary_team_contacts was not significantly different between the Pretest and Posttest categories of Time Period. The results are presented in Table 5. A bar plot of the means is presented in Figure 5.

\section{Table 5}

Two-Tailed Independent Samples $t$-Test for Number_of_Multidisplinary_team_contacts by Time Period 


\begin{tabular}{|c|c|c|c|c|c|c|c|}
\hline \multirow[b]{2}{*}{ Variable } & \multicolumn{2}{|c|}{ Pretest } & \multicolumn{2}{|c|}{ Posttest } & \multirow[b]{2}{*}{$t$} & \multirow[b]{2}{*}{$p$} & \multirow[b]{2}{*}{$d$} \\
\hline & $M$ & $S D$ & $M$ & $S D$ & & & \\
\hline Number_of_Multidisplinary_team_contacts & 2.50 & 1.17 & 2.62 & 0.97 & -0.31 & .755 & 0.11 \\
\hline
\end{tabular}

Note. $\mathrm{N}=33$. Degrees of Freedom for the $t$-statistic $=31 . d$ represents Cohen's $d$.

\section{Figure 5}

The mean of Number_of_Multidisplinary_team_contacts by levels of Time Period

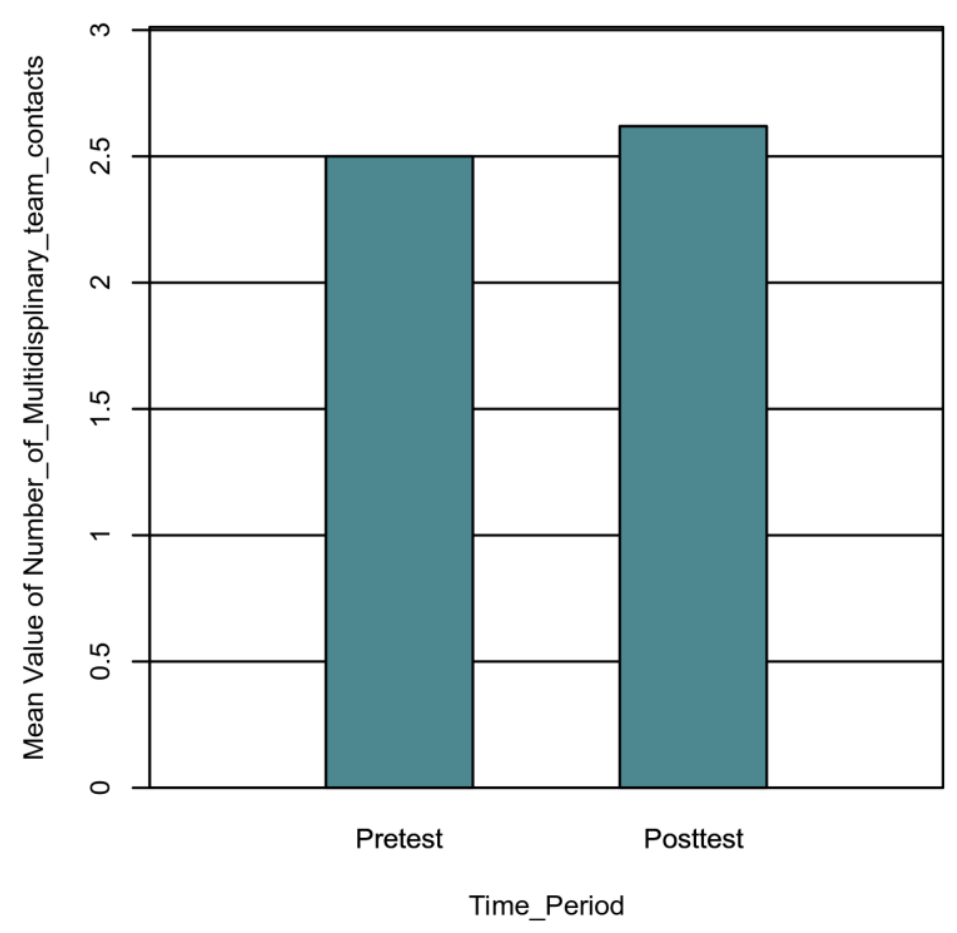




\section{Impact}

At the VA, the clinical staff are not new to rules, regulations, and policies. Therefore, establishing a staff best practices wound care policy focusing on EMR documentation was needed at the VA to improve multidisciplinary collaboration to decrease wound incidences and improve proper wound care management. As a result of the intervention implementation, the clinical staff were able to see new perspectives of reducing and preventing wounds in their hospital. Unfortunately, due to the present pandemic, the COVID-19, and its restrictions, not a huge positive outcome after implementing the intervention was observed.

Although the wound care educator educated the staff on the "Braden Scale" and the "SCI-PUMT" tools policies, utilizing the intervention implemented on using the tools will go a long way in helping in reducing wounds in the facility. For the intervention to be sustained, the unit manager(s) should help reinforce the intervention implemented and hold the staff accountable through frequent EMR wound care chart auditing. While the charge nurses remind the clinical staff of the use and proper documentation of the Braden scale and SCI-PUMT tools during daily hurdle.

Some of the barriers and limitations encountered were the inability to follow up face-toface with the staff due to the implemented restrictions due to COVID-19 and wound staging and charting inconsistency. In addition, due to inadequate staffing, the available staff were more focused on direct care to the patient instead of documentation. More awareness needs to be created among the clinical staff. Some of the staff were not aware that wound care documentation using the tools mentioned above should be performed on every patient and not only on the patients with wounds. Reimplementation of the project is recommended where the barriers mentioned above would be removed, allowing for a greater opportunity for staff 
mentoring, coaching, and oversight to ensure processes are fully completed based on the protocols.

\section{Dissemination Plan}

After successfully implementing the EBP change project, the result of the change project was disseminated within the facility. Within the facility, the Chief Nursing Officer (CNO), Chief Medical Officer (CMO), the unit managers, project manager preceptor, wound care specialist, dietitian, physical therapists, occupational therapists, patients' representative, nurses representatives were present during the dissemination of the result with PowerPoint presentation through a Zoom virtual presentation. Permission for disseminating the result at the facility level was obtained from the hospital executives, the date, time, and location were fixed. The responsible parties for the dissemination were notified and reminded through email of the event's location, date, and time. Within the inpatient unit, a poster presentation of the EBP change result was posted on the unit.

For the professional community, the result of the project will be archived at the University of Saint Augustine for Health Sciences scholarship and open access repository (SOAR) for the accessibility of the students and faculty. In addition, the EBP change project will be shared at the Michigan Council of Nurse Practitioners annual conference scheduled for 2022. Finally, the Journal of the American Association of Nurse Practitioners (JAANP) has been selected for the publication of the EBP change project. The JAANP supports evidence-based practices, and the journal publications are used to keep nurse practitioners informed of the latest best practices (AANP, 2020). 


\section{Conclusion}

The goal of this evidence-based project was to establish wound care policy with a focus on EMR documentation supporting improved identification of patient wound status as an effort to decrease patient wound incidences and improve proper wound management as aligned with VA expectations. The issue with current practice was the non-compliance with current best practices which was supposed to have been alleviated through the new wound care policy updates and evaluation of wound care documentation. Unfortunately, due to some barriers encountered by the project manager, the result was not statistically significant. A reimplementation of the project without barriers is recommended by the project manager.

The project was defined by the following PICOT question: Among the wound care clinical staff members at the VA (P) will establishment of a staff best practices wound care policy focusing on EMR documentation (I) compared to current staff practices (C) improve multidisciplinary collaboration to decrease wound incidences and improve proper wound care management $(\mathrm{O})$ within two months of initiation of the practice change (T)? The Johns Hopkins evidence-based practice framework guided the project, and the Lewin change theory defined the project steps. The DNP student was the designated project manager who led the change project, collected, and analyzed the data, and disseminated of results to stakeholders. The project was complete in 8 weeks. 


\section{References}

Adibelli, S. \& Korkmaz, F. (2019). Pressure injury risk assessment in intensive care units:

Comparison of the reliability and predictive validity of the Braden and Jackson/Cubbin scales. Journal of Clinical Nursing, 28(23-24), 4595-4605.

https://doi.org/10.1111/jocn.15054

American Association of Nurse Practitioners. (2020). Journal of the American Association of Nurse Practitioners. https://www.aanp.org/education/publications/jaanp

Awali, Z. M., Nagshabandi, E. A., \& Elgmail, A. (2018). The effects of implementing pressure ulcer prevention educational protocol on the nurses' knowledge, attitude, and practices. Nursing Primary Care, 2(4), 1-7. https://www.iosrjournals.org/iosr-jnhs/papers/vol7issue6/Version-11/J0706116069.pdf

Bamohammed, A., Mohidin, S., George, B., \& Al-Aidarous, S. (2018). An observation study on wound dressing performance among nurses in adult units. Journal of Nursing and Health Science, 7(3), 1-6. https://doi.10.9790/1959-0703020106

Batras, D., Duff, C., \& Smith, B. J. (2016). Organizational change theory: Implications for health promotion practice. Health Promotion International, 31(1), 231-241. https://doi.org/10.1093/heapro/dau098

Braden scale for predicting pressure score risk. (2014). https://jessbrantnerwvudietetics.wordpress.com/2014/01/23/what-is-the-braden-scale/

Chaghari, M., Ebadi, A., Ameryoun, A., \& Safari, M. (2016). An attempt for empowering education: A qualitative study of in-service training of nursing personnel. Iranian Journal of Nursing and Midwifery Research, 21(5), 498-503. https://pubmed.ncbi.nlm.nih.gov/27904634/ 
Conover, W. J., \& Iman, R. L. (1981). Rank transformations as a bridge between parametric and nonparametric statistics. The American Statistician, 35(3), 124-129. https://doi.org/10.1080/00031305.1981.10479327

Cowan, L., Garvan, C., Rugs, D., Barks, L, Chavez, M., \& Orozco. (2018). Pressure injury education in the department of veterans affairs. Journal of Wound Ostomy Continence Nursing, 45(5),419-424. https://doi.1097/WON.0000000000000468

Cross, R., Jennings, N., McGuiness, W., \& Miller, C. (2016) Profiling wound management in the emergency department: A descriptive analysis. Australia Emergency Nursing Journal, 19(3), 166-171. https://doi.org/10.1016/j.aenj.2016.06.003

Dang, D., \& Dearholt, S. (2017). Johns Hopkins nursing evidence-based practice. https://guides.upstates,edu/JHNEBP

Department of Veterans Affairs Office of Inspector General. (2015). Combined assessment program summary report: Evaluation of pressure ulcer prevention and management at veterans health administration facilities. https://www.va.gov/oig/pubs/VAOIG-14-0513290.pdf

Department of Veterans Affairs Veterans Health Administration. (n. d.). VHA directive 1352, prevention and management of pressure injuries. www.va.gov/vhapublications/ViewPublication.asp?pub_ID=8274

Driver, V. R., Gould, L. J., Dotson, P., Allen, L. L., Carter, M. J., \& Bolton, L. L. (2019). Evidence supporting wound care endpoints relevant to clinical practice and patients' lives. Part 2. Literature survey. https://doi.org/10.1111/wrr.12676

Goudy-Egger, L., \& Dunn, K. S. (2018). Use of continuing education to increase nurses' knowledge of chronic wound care management. Journal for Continuing Education in 
Nursing, 49(10), 454-459. https://0b32q1tld-mp03-y-https-www-proquest-com.prxusa.lirn.net/docview/2112266917

Gupta, N., Loong, B., \& Leong, C. (2012). Comparing and contrasting knowledge of pressure ulcer assessment, prevention, and management in people with spinal cord injury among nursing staff working in two metropolitan spinal units and rehabilitation medicine training specialists in a three-way comparison. Spinal Cord, 50, 159-164. https://doi.org/10.1038/sc.2011.88

Intellectus Statistics [Online computer software]. (2021). Intellectus Statistics. https://analyze.intellectusstatistics.com/

Johnson-Kunjukutty, S., \& Delille, C. (2019). Impact of chronic osteomyelitis on wound healing and the quality of life of the patient with a chronic wound. World Council of Enterostomal Therapists Journal, 39(2), 34-40. https://doi.org/10.33235/wcet.39.2.34-40

Kielo, E., Suhonen, R., Salminen, L., \& Scott, M. (2019). Competence areas for registered nurses and podiatrists in chronic wound care, and their role in wound care practice. Journal of Clinical Nursing (John Wiley \& Sons, Inc.), 28(21/22), 4021-4034. https://doi.org/10.1111/jocn.14991

McCluskey, P. \& McCarthy, G. (2017). Nurses' knowledge and competence in wound management. Wounds U.K., 8(2), 37-47. http://0b30c1stq.mp03.y.http.eds.b.ebscohost.com.prxusa.lirn.net/eds/pdfviewer/pdfviewer?vid=4\&sid=f15ff57b-f08d-4363-8c00cd0dbea14a5d\%40pdc-v-sessmgr04

Mulholland, B. (2017). 8 Critical change management models to evolve and survive. Process.st. https://www.process.st/change-management-models/\#kubler-ross-change-curve 
Mwebaza, I., Katende, G., Groves., S., \& Nankumbi, J. (2014). Nurse’ knowledge, practices, and barriers in care of patients with pressure ulcers in a Ugandan teaching hospital. Nursing Research and Practice. https://doi.org/10.1155/2014/973602

Nussbaum, S. R., Carter, M. J., Fife, C. E., DaVanzo, J., Haught, R., Nusgart, M., \& Cartwright, E. F. (2018). An economic evaluation of the impact, cast, and Medicare policy implications of chronic nonhealing wounds. Value in Health, 21, 27-32. http://dx.doi.org/10.1016/j.jval.2017.07.007

Oseni, O. \& Adejumo, P. (2014). Nurses; Reported practice and knowledge of wound assessment, assessment tools, and documentation in a selected hospital in Lagos, Nigeria. African Journal of Medical Sciences, 43(2), 149-157.

https://pubmed.ncbi.nlm.nih.gov/25474991/

Ousey, K., \& Blackburn, J. (2019). The positive impact of training and education on nurses' competence and confidence. Wounds U.K., 15 (1), 7-8. https://www.wounds$\underline{\text { uk.com/journals/issue/570/article-details/the-positive-impact-of-training-and-education- }}$ on-nurses-competence-and-confidence

PRISMA transparent reporting of systematic reviews and meta-analysis. (2015). http://www.prisma-statement.org/PRISMAStatement/FlowDiagram.aspx

Razali, N. M., \& Wah, Y. B. (2011). Power comparisons of Shapiro-Wilk, KolmogorovSmirnov, Lilliefors, and Anderson-Darling tests. Journal of Statistical Modeling and Analytics, 2(1), 21-33. http://0b30dyyho.mp03.y.http.eds.a.ebscohost.com.prxusa.lirn.net/eds/detail/detail?vid=1\&sid=4c962cd9-ea61-403b-9ec98fe1c3e60b62\%40sdc-v- 
sessmgr03\&bdata=JnNpdGU9ZWRzLWxpdmU\%3d\#AN=edsgcl.504847744\&db=edsgi

$\mathrm{n}$

Sen, C. (2019). Human wounds and its burden: A updated compendium of estimates. https://doi.10.1089/wound.2019.0946

Seo, Y., \& Roh, Y. S. (2020). Effects of pressure ulcer prevention training among nurses in longterm care hospitals. Nurse Education Today, 84. https://doi.org/10.1016/j.nedt.2019.104225

Soban, L. M., Kim, L., Yuan, A., \& Miltner, R. S. (2017). Organizational strategies to implement hospital pressure ulcer prevention programmes: Findings from a national survey. Journal of Nursing Management, 25, 457-467. https://doi.org.10.1111/jonm.12416

Thomason, S., Luther, S., Powell-Cope, G., Harrow, J. J., \& Palacio, P. (2014). Validity and reliability of a pressure ulcer monitoring tool for persons with spinal cord impairment. Journal of Spinal Cord Medicine, 37(3), 317-327. https://pubmed.ncbi.nlm.nih.gov/24621044/

Thomason, S.S., Powell-Cope, G., Peterson, M, J., Guihan, M., Wallen, E. S., Olney, C., \& Bates-Jensen, B. (2016). A multisite quality improvement project to standardize the assessment of pressure ulcer healing in veterans with spinal cord injuries/disorders. Advances in Skin and Wound Care, 29(6), 269-276. https://doi. 10.1097/01.ASW.0000482283.85306.8f

U.S. Department of Veterans Affairs. Mission, vision, core values \& goals. (n. d.). https://www.va.gov/about_va/mission.asp 
Walker, C. A., Rahman, A., Gipson-Jones, T. \& Harris, C. M. (2019). Hospitalists' needs assessment and perceived barriers in wound care management. Journal of Wound Ostomy Continence Nursing,46(2), 98-105. https://doi.10.1097/WON.0000000000000512 


\section{Appendix A: PRISMA Reporting}

\section{PRISMA}

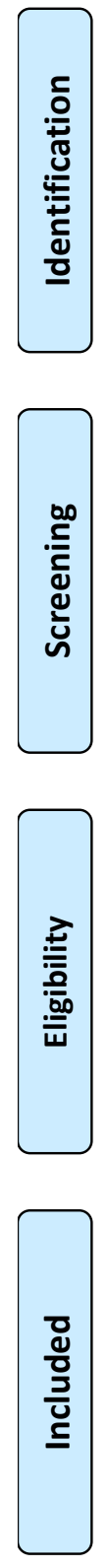

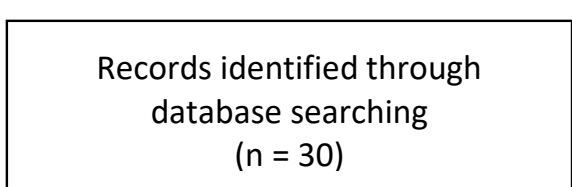

$(n=30)$
Additional records identified through other sources

$$
(n=0)
$$

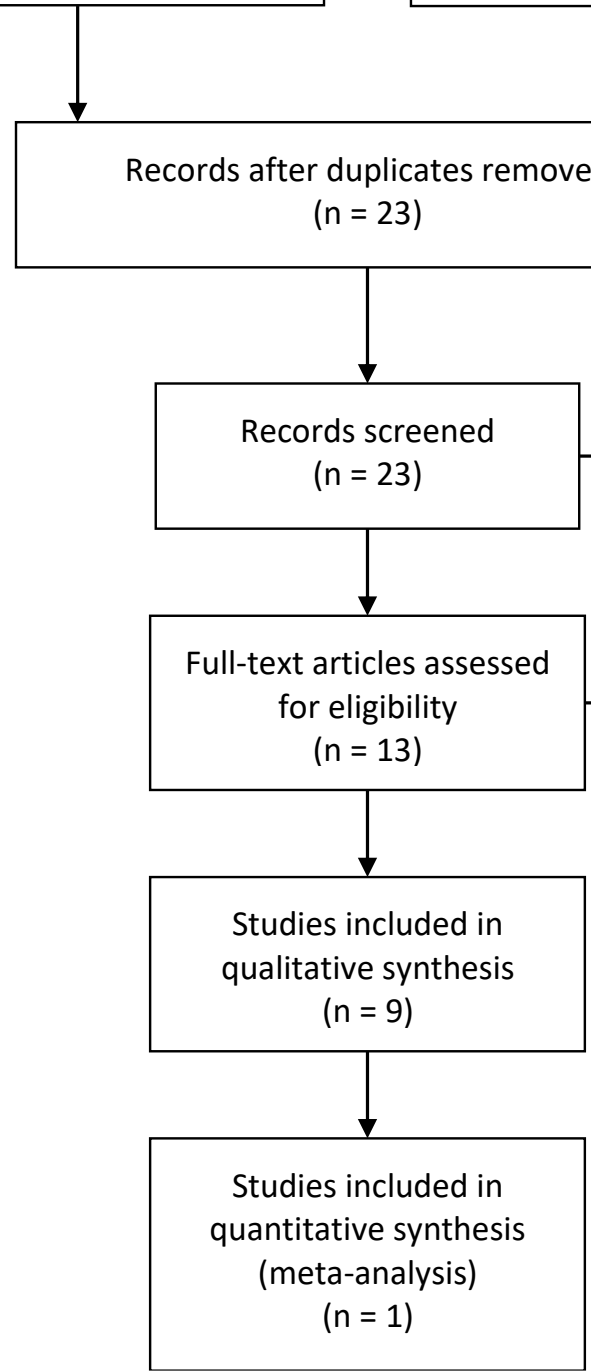

Records excluded

$(n=10)$

Full-text articles excluded, with reasons

$$
(n=3)
$$

PRISMA transparent reporting of systematic reviews and meta-analysis. (2015).

http://www.prisma-statement.org/PRISMAStatement/FlowDiagram.aspx 
Appendix B: Primary Research Evidence

\begin{tabular}{|c|c|c|c|}
\hline Citation & Design & $\begin{array}{l}\text { Level of } \\
\text { evidence } \\
\text { according } \\
\text { to John } \\
\text { Hopkins } \\
\text { EBP } \\
\text { Model }\end{array}$ & $\begin{array}{l}\text { Grade of } \\
\text { evidence } \\
\text { according } \\
\text { to John } \\
\text { Hopkins } \\
\text { EBP } \\
\text { Model }\end{array}$ \\
\hline $\begin{array}{l}\text { Bamohammed, A., Mohidin, S., George, B., \& Al-Aidarous, S. (2018). } \\
\text { An observation study on wound dressing performance among nurses in } \\
\text { adult units. Journal of Nursing and Health Science, 7(3), 1-6. } \\
\text { https://doi.10.9790/1959-0703020106 }\end{array}$ & $\begin{array}{l}\text { A cross- } \\
\text { sectional } \\
\text { observational } \\
\text { study. }\end{array}$ & Level III & Grade B \\
\hline $\begin{array}{l}\text { Cross, R., Jennings, N., McGuiness, W., \& Miller, C. (2016) Profiling } \\
\text { wound management in the emergency department: A descriptive analysis. } \\
\text { Australia Emergency Nursing Journal, 19(3), 166-171. } \\
\text { https://doi.org/10.1016/j.aenj.2016.06.003 }\end{array}$ & $\begin{array}{l}\text { Retrospective } \\
\text { descriptive } \\
\text { review. }\end{array}$ & Level IV & Grade B \\
\hline $\begin{array}{l}\text { Cowan, L., Garvan, C., Rugs, D., Barks, L, Chavez, M., \& Orozco. } \\
\text { (2018). Pressure injury education in the department of veterans affairs. } \\
\text { Journal of Wound Ostomy Continence Nursing, 45(5),419-424. } \\
\text { https://doi.1097/WON.0000000000000468 }\end{array}$ & $\begin{array}{l}\text { A cross- } \\
\text { sectional, } \\
\text { descriptive } \\
\text { study. }\end{array}$ & Level III & $\begin{array}{l}\text { Grade } \\
\text { A/B }\end{array}$ \\
\hline $\begin{array}{l}\text { Goudy-Egger, L, \& Dunn, K. S. (2018). Use of continuing education to } \\
\text { increase nurses' knowledge of chronic wound care management. Journal } \\
\text { for Continuing Education in Nursing, } 49(10), 454-459 . \underline{\text { https://0b32q1tld- }} \\
\text { mp03-y-https-www-proquest-com.prx-usa.lirn.net/docview/2112266917 }\end{array}$ & $\begin{array}{l}\text { Pretest- } \\
\text { posttest } \\
\text { research } \\
\text { design. }\end{array}$ & Level III & $\begin{array}{l}\text { Grade } \\
\text { A/B }\end{array}$ \\
\hline $\begin{array}{l}\text { Gupta, N., Loong, B., \& Leong. (2012). Comparing and contrasting } \\
\text { knowledge of pressure ulcer assessment, prevention, and management in } \\
\text { people with spinal cord injury among nursing staff working in two } \\
\text { metropolitan spinal units and rehabilitation medicine training specialists } \\
\text { in a three-way comparison. Spinal Cord, 50, 159-164. } \\
\text { https://doi.org/10.1038/sc.2011.88 }\end{array}$ & $\begin{array}{l}\text { Prospective } \\
\text { Survey } \\
\text { design study }\end{array}$ & Level III & Grade C \\
\hline $\begin{array}{l}\text { Kielo, E., Suhonen, R., Salminen, L., \& Scott, M. (2019). Competence } \\
\text { areas for registered nurses and podiatrists in chronic wound care, and } \\
\text { their role in wound care practice. Journal of Clinical Nursing (John } \\
\text { Wiley \& Sons, Inc.), 28(21/22), 4021-4034. } \\
\text { https://doi.org/10.1111/jocn.14991 }\end{array}$ & $\begin{array}{l}\text { Qualitative } \\
\text { design. }\end{array}$ & Level II & $\begin{array}{l}\text { Grade } \\
\mathrm{A} / \mathrm{B}\end{array}$ \\
\hline
\end{tabular}




\begin{tabular}{|l|l|l|l|}
\hline $\begin{array}{l}\text { McCluskey, P. \& McCarthy, G. (2017). Nurses' knowledge and } \\
\text { competence in wound management. Wounds U.K., 8(2), 37-47. } \\
\text { http://0b30boj34.mp02.y.http.eds.b.ebscohost.com.prx- } \\
\text { usa.lirn.net/eds/pdfviewer/pdfviewer?vid=1\&sid=fca5d1c6-6695-4460- } \\
\text { af28-bfd06906c515\%40pdc-v-sessmgr01 }\end{array}$ & $\begin{array}{l}\text { A } \\
\text { quantitative, } \\
\text { descriptive } \\
\text { study. }\end{array}$ & Level IV & Grade A \\
\hline $\begin{array}{l}\text { Mwebaza, I., Katende, G., Groves., S., \& Nankumbi, J. (2014). Nurse' } \\
\text { knowledge, practices, and barriers in care of patients with pressure ulcers } \\
\text { in a Ugandan teaching hospital. Nursing Research and Practice, 2014. } \\
\text { https://doi.org/10.1155/2014/973602 }\end{array}$ & $\begin{array}{l}\text { A descriptive } \\
\text { cross- } \\
\text { sectional } \\
\text { quantitative } \\
\text { study. }\end{array}$ & Level II & Grade B \\
\hline $\begin{array}{l}\text { Seo, Y., and Roh, Y. S. (2020). Effects of pressure ulcer prevention } \\
\text { training among nurses in long-term care hospitals. Nurse Education } \\
\text { Today, 84. https://doi.org/10.1016/j.nedt.2019.104225 }\end{array}$ & $\begin{array}{l}\text { Comparison } \\
\text { of group } \\
\text { pretest- } \\
\text { posttest } \\
\text { design. }\end{array}$ & Level II & Grade B \\
\hline
\end{tabular}


Appendix C: Systematic Review

\begin{tabular}{|c|c|c|}
\hline Citation & $\begin{array}{l}\text { Level of evidence } \\
\text { according to John } \\
\text { Hopkins EBP Model }\end{array}$ & $\begin{array}{l}\text { Grade of evidence } \\
\text { according to John } \\
\text { Hopkins EBP Model }\end{array}$ \\
\hline $\begin{array}{l}\text { Walker, R. M., Gilleespie, B. M., McInnes, E., } \\
\text { Moore, Z., Eskes, A. M., Patton, D., Harbeck, E. } \\
\text { L., White, C., Scott, I. A., \& Chaboyer, W. } \\
\text { (2020). Prevention and treatment of pressure } \\
\text { injuries: A meta-synthesis of Cochrane reviews. } \\
\text { Journal of Tissue Viability, S0965-206X (20), 1- } \\
\text { 17. https://doi.org/10.1016/j.jtv.2020.05.004 }\end{array}$ & Level 1 & Grade A \\
\hline
\end{tabular}


Appendix D: Summary of Primary Research Evidence

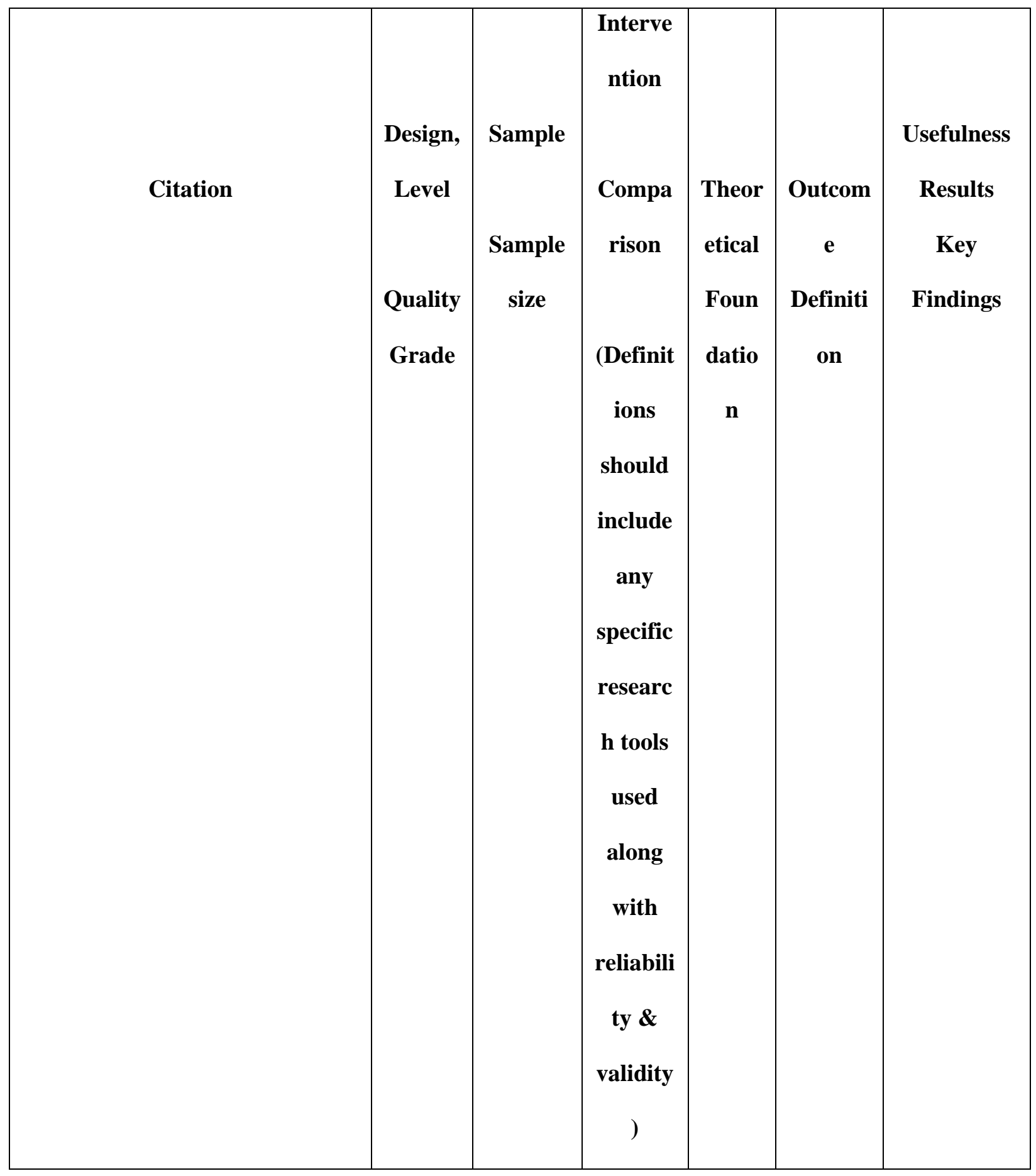




\begin{tabular}{|c|c|c|c|c|c|c|}
\hline $\begin{array}{l}\text { Bamohammed, A., Mohidin, S., } \\
\text { George, B., \& Al-Aidarous, S. } \\
\text { (2018). An observation study } \\
\text { on wound dressing performance } \\
\text { among nurses in adult units. } \\
\text { Journal of Nursing and Health } \\
\text { Science, } 7(3), 1-6 . \\
\text { https://doi.10.9790/1959- } \\
\underline{0703020106}\end{array}$ & $\begin{array}{l}\text { A } \\
\text { cross- } \\
\text { section } \\
\text { al } \\
\text { observ } \\
\text { ational } \\
\text { study. } \\
\text { Level } \\
\text { III. } \\
\text { Grade } \\
\text { B }\end{array}$ & $\begin{array}{l}\text { Clinical } \\
\text { staff } \\
\text { membe } \\
\text { rs. } \\
\mathrm{N}=41\end{array}$ & $\begin{array}{l}\text { SPSS } \\
\text { version } \\
21 \text { was } \\
\text { used to } \\
\text { analyze } \\
\text { the } \\
\text { data. } \\
\text { Pearso } \\
\text { n } \\
\text { correlat } \\
\text { ion, } \\
\text { ANOV } \\
\text { A, and } \\
\text { t-tests } \\
\text { were } \\
\text { used to } \\
\text { compar } \\
\text { e group } \\
\text { means, } \\
\text { and } \\
\text { alpha } \\
\text { was set } \\
\text { at } 0.05 \\
\text { to } \\
\text { compar } \\
\text { e both } \\
\text { observa } \\
\text { tion } \\
\text { groups } \\
\text { in the } \\
\text { study. }\end{array}$ & $\begin{array}{l}\text { No } \\
\text { theor } \\
\text { etical } \\
\text { found } \\
\text { ation } \\
\text { was } \\
\text { stated }\end{array}$ & $\begin{array}{l}\text { Educati } \\
\text { onal } \\
\text { course } \\
\text { on } \\
\text { wound } \\
\text { care } \\
\text { manage } \\
\text { ment is } \\
\text { essentia } \\
\text { l to the } \\
\text { clinical } \\
\text { state. }\end{array}$ & $\begin{array}{l}\text { The mean } \\
\text { score of the } \\
\text { clinicians } \\
\text { who } \\
\text { adhered to } \\
\text { the } \\
\text { educational } \\
\text { wound care } \\
\text { manageme } \\
\text { nt } \\
\text { technique } \\
\text { was high, } \\
\text { demonstrat } \\
\text { ing the } \\
\text { importance } \\
\text { of wound } \\
\text { care } \\
\text { education. }\end{array}$ \\
\hline $\begin{array}{l}\text { Cross, R., Jennings, N., } \\
\text { McGuiness, W., \& Miller, C. } \\
\text { (2016) Profiling wound } \\
\text { management in the emergency } \\
\text { department: A descriptive } \\
\text { analysis. Australia Emergency } \\
\text { Nursing Journal, 19(3), 166- } \\
171 . \\
\text { https://doi.org/10.1016/j.aenj.20 } \\
16.06 .003\end{array}$ & $\begin{array}{l}\text { Retros } \\
\text { pective } \\
\text { descrip } \\
\text { tive } \\
\text { review } \\
\text { - } \\
\text { Level } \\
\text { IV } \\
\text { Grade } \\
\text { B }\end{array}$ & Patients & $\begin{array}{l}\text { Data } \\
\text { was } \\
\text { extract } \\
\text { ed } \\
\text { through } \\
\text { VEMD } \\
\text { using } \\
\text { ICD } \\
\text { (versio } \\
\text { n 10). } \\
\text { SPSS } \\
\text { (versio } \\
\text { n 22) } \\
\text { was }\end{array}$ & $\begin{array}{l}\text { No } \\
\text { theor } \\
\text { etical } \\
\text { found } \\
\text { ation } \\
\text { was } \\
\text { stated }\end{array}$ & $\begin{array}{l}\text { The } \\
\text { patients } \\
\text { that } \\
\text { were } \\
\text { not } \\
\text { adequat } \\
\text { ely } \\
\text { profiled } \\
\text { in the } \\
\text { emerge } \\
\text { ncy } \\
\text { depart } \\
\text { ment } \\
\text { ended }\end{array}$ & $\begin{array}{l}\text { Education/ } \\
\text { knowledge } \\
\text { of nurses } \\
\text { regarding } \\
\text { wound care } \\
\text { is needed } \\
\text { in the } \\
\text { profiling of } \\
\text { wounds to } \\
\text { provide } \\
\text { high- } \\
\text { quality } \\
\text { patient } \\
\text { care. }\end{array}$ \\
\hline
\end{tabular}




\begin{tabular}{|c|c|c|c|c|c|c|}
\hline & & & $\begin{array}{l}\text { used to } \\
\text { analyze } \\
\text { the } \\
\text { data. }\end{array}$ & & $\begin{array}{l}\text { up } \\
\text { admitte } \\
\mathrm{d} \\
\text { instead } \\
\text { of been } \\
\text { dischar } \\
\text { ged } \\
\text { home. }\end{array}$ & \\
\hline $\begin{array}{l}\text { Cowan, L., Garvan, C., Rugs, } \\
\text { D., Barks, L, Chavez, M., \& } \\
\text { Orozco. (2018). Pressure injury } \\
\text { education in the department of } \\
\text { veterans affairs. Journal of } \\
\text { Wound Ostomy Continence } \\
\text { Nursing, 45(5),419-424. } \\
\text { https://doi.1097/WON.0000000 } \\
\underline{000000468}\end{array}$ & $\begin{array}{l}\text { A } \\
\text { cross- } \\
\text { section } \\
\text { al, } \\
\text { descrip } \\
\text { tive } \\
\text { study. } \\
\text { Level } \\
\text { III } \\
\text { Grade } \\
\text { A/B }\end{array}$ & $\begin{array}{l}\text { Veteran } \\
\text { s' } \\
\text { Health } \\
\text { Admini } \\
\text { stration } \\
\text { (VHA) } \\
\text { wound } \\
\text { care } \\
\text { provide } \\
\text { rs and } \\
\text { clinicia } \\
\text { ns. } \\
\\
\mathrm{N}= \\
1726\end{array}$ & $\begin{array}{l}\text { Data } \\
\text { were } \\
\text { compil } \\
\text { ed and } \\
\text { the } \\
\text { integrit } \\
\text { y of the } \\
\text { data } \\
\text { checke } \\
\text { d by } \\
\text { the } \\
\text { NCOD } \\
\text { analyst } \\
\text { s. SAS } \\
\text { (versio } \\
n \text { 9.4) } \\
\text { was } \\
\text { used to } \\
\text { summa } \\
\text { rize } \\
\text { and } \\
\text { interpre } \\
\mathrm{t} \text { the } \\
\text { finding } \\
\text { s. } \\
\text { Provide } \\
\text { r types } \\
\text { and } \\
\text { level of } \\
\text { experie } \\
\text { nce } \\
\text { were } \\
\text { used to } \\
\text { compar } \\
\text { e } \\
\text { respons } \\
\text { es. }\end{array}$ & $\begin{array}{l}\text { No } \\
\text { theor } \\
\text { etical } \\
\text { found } \\
\text { ation } \\
\text { was } \\
\text { stated }\end{array}$ & $\begin{array}{l}\text { Wound } \\
\text { care } \\
\text { educati } \\
\text { on and } \\
\text { docume } \\
\text { ntation } \\
\text { were } \\
\text { identifi } \\
\text { ed by } \\
\text { the } \\
\text { clinical } \\
\text { staff as } \\
\text { the } \\
\text { biggest } \\
\text { issue of } \\
\text { P.I. } \\
\text { prevent } \\
\text { ion and } \\
\text { manage } \\
\text { ment. }\end{array}$ & $\begin{array}{l}\text { Clinical } \\
\text { staff } \\
\text { requires } \\
\text { education } \\
\text { and } \\
\text { improved } \\
\text { documentat } \\
\text { ion to } \\
\text { prevent } \\
\text { P.I., } \\
\text { manage, } \\
\text { and } \\
\text { evaluate } \\
\text { the wound } \\
\text { adequately. } \\
\text { In } \\
\text { preference } \\
\text { to the type } \\
\text { of wound } \\
\text { care } \\
\text { training, } \\
17 \% \text { of the } \\
\text { clinical } \\
\text { staff } \\
\text { indicated a } \\
\text { preference } \\
\text { for online } \\
\text { wound care } \\
\text { gaming, } \\
\text { while } 82 \% \\
\text { prefer face- } \\
\text { to-face } \\
\text { training. }\end{array}$ \\
\hline
\end{tabular}




\begin{tabular}{|c|c|c|c|c|c|c|}
\hline & & & $\begin{array}{l}\text { Conten } \\
\mathrm{t} \\
\text { analysi } \\
\mathrm{s} \text { was } \\
\text { used } \\
\text { for } \\
\text { qualitat } \\
\text { ive } \\
\text { analysi } \\
\text { s of } \\
\text { open- } \\
\text { ended } \\
\text { text } \\
\text { respons } \\
\text { e } \\
\text { questio } \\
\text { ns. }\end{array}$ & & & \\
\hline $\begin{array}{l}\text { Goudy-Egger, L, \& Dunn, K. S. } \\
\text { (2018). Use of continuing } \\
\text { education to increase nurses' } \\
\text { knowledge of chronic wound } \\
\text { care management. Journal for } \\
\text { Continuing Education in } \\
\text { Nursing, 49(10). 454-459. } \\
\text { https://0b32q1tld-mp03-y-https- } \\
\text { www-proquest-com.prx- } \\
\underline{\text { usa.lirn.net/docview/211226691 }} \\
\underline{7}\end{array}$ & $\begin{array}{l}\text { Pretest } \\
- \\
\text { posttes } \\
\mathrm{t} \\
\text { researc } \\
\mathrm{h} \\
\text { design. } \\
\text { Level } \\
\text { III } \\
\text { Grade: } \\
\text { A/B }\end{array}$ & $\begin{array}{l}\text { Rando } \\
\text { mly } \\
\text { selected } \\
\text { clinical } \\
\text { staff. } \\
\mathrm{N}=31\end{array}$ & $\begin{array}{l}\text { SPSS } \\
\text { (versio } \\
\text { n 21.0) } \\
\text { was } \\
\text { used to } \\
\text { analyze } \\
\text { the } \\
\text { data. } \\
\text { The } \\
\text { researc } \\
\text { h } \\
\text { questio } \\
\text { n was } \\
\text { address } \\
\text { ed } \\
\text { using a } \\
\text { paired- } \\
\text { sample } \\
\text { s } t \text {-test. } \\
\text { Pretest } \\
\text { of the } \\
\text { particip } \\
\text { ants' } \\
\text { knowle } \\
\text { dge of } \\
\text { wound } \\
\text { care }\end{array}$ & $\begin{array}{l}\text { No } \\
\text { theor } \\
\text { etical } \\
\text { found } \\
\text { ation } \\
\text { was } \\
\text { stated }\end{array}$ & $\begin{array}{l}\text { The } \\
\text { need } \\
\text { for } \\
\text { wound } \\
\text { care } \\
\text { educati } \\
\text { on } \\
\text { increas } \\
\text { es } \\
\text { among } \\
\text { clinical } \\
\text { staff in } \\
\text { the } \\
\text { health } \\
\text { care } \\
\text { system. }\end{array}$ & $\begin{array}{l}\text { There was } \\
\text { a } \\
\text { statistically } \\
\text { significant } \\
\text { increase in } \\
\text { wound care } \\
\text { manageme } \\
\text { nt's clinical } \\
\text { staff } \\
\text { knowledge } \\
\text { after } \\
\text { attending } \\
\text { the wound } \\
\text { care } \\
\text { educational } \\
\text { workshop. } \\
\text { Showing } \\
\text { that there is } \\
\text { a } \\
\text { relationshi } \\
\text { p between } \\
\text { clinical } \\
\text { staff } \\
\text { wound care } \\
\text { manageme } \\
\text { nt } \\
\text { education }\end{array}$ \\
\hline
\end{tabular}




\begin{tabular}{|c|c|c|c|c|c|c|}
\hline & & & $\begin{array}{l}\text { was } \\
\text { compar } \\
\text { ed to } \\
\text { posttest } \\
\text { after } \\
\text { wound } \\
\text { care } \\
\text { educati } \\
\text { on }(p< \\
.05)\end{array}$ & & & $\begin{array}{l}\text { and wound } \\
\text { outcome. } \\
\text { The study } \\
\text { was limited } \\
\text { due to the } \\
\text { small } \\
\text { sample } \\
\text { size. } \\
\text { Another } \\
\text { limitation } \\
\text { was that } \\
\text { the nursing } \\
\text { knowledge } \\
\text { was not } \\
\text { clinically } \\
\text { tested } \\
\text { rather, it } \\
\text { was tested } \\
\text { on paper. }\end{array}$ \\
\hline $\begin{array}{l}\text { Gupta, N., Loong, B., \& Leong. } \\
\text { (2012). Comparing and } \\
\text { contrasting knowledge of } \\
\text { pressure ulcer assessment, } \\
\text { prevention, and management in } \\
\text { people with spinal cord injury } \\
\text { among nursing staff working in } \\
\text { two metropolitan spinal units } \\
\text { and rehabilitation medicine } \\
\text { training specialists in a three- } \\
\text { way comparison. Spinal Cord, } \\
\text { 50, 159-164. } \\
\text { https://doi.org/10.1038/sc.2011. } \\
\underline{88}\end{array}$ & $\begin{array}{l}\text { Prospe } \\
\text { ctive } \\
\text { Survey } \\
\text { design } \\
\text { study. } \\
\text { Level } \\
\text { III } \\
\text { Grade } \\
\text { C }\end{array}$ & $\begin{array}{l}\text { Nurses. } \\
\mathrm{N}=28\end{array}$ & $\begin{array}{l}\text { Data } \\
\text { were } \\
\text { analyze } \\
\text { d with } \\
\text { softwar } \\
\text { e } \\
\text { packag } \\
\text { e R } \\
\text { (versio } \\
\text { n 2.8). } \\
\text { The } \\
\text { ANOV } \\
\text { A test } \\
\text { was } \\
\text { used in } \\
\text { detecti } \\
\text { ng the } \\
\text { average } \\
\text { score } \\
\text { differe } \\
\text { nces by } \\
\text { work } \\
\text { area, } \\
\text { years } \\
\text { of }\end{array}$ & $\begin{array}{l}\text { No } \\
\text { theor } \\
\text { etical } \\
\text { found } \\
\text { ation } \\
\text { was } \\
\text { stated }\end{array}$ & $\begin{array}{l}\text { There } \\
\text { was a } \\
\text { differen } \\
\text { ce in } \\
\text { knowle } \\
\text { dge of } \\
\text { P.I. } \\
\text { prevent } \\
\text { ion and } \\
\text { manage } \\
\text { ment } \\
\text { among } \\
\text { the } \\
\text { nurses. }\end{array}$ & $\begin{array}{l}\text { A gap in } \\
\text { knowledge } \\
\text { among } \\
\text { clinical } \\
\text { staff in the } \\
\text { care of } \\
\text { patients } \\
\text { with SCI } \\
\text { was noted } \\
\text { where } \\
\text { doctors } \\
\text { score } \\
\text { higher in } \\
\text { SCI } \\
\text { knowledge } \\
\text { than } \\
\text { nurses. } \\
\text { The } \\
\text { authors } \\
\text { recommen } \\
\text { d the } \\
\text { implement } \\
\text { ation of a } \\
\text { wound } \\
\text { manageme }\end{array}$ \\
\hline
\end{tabular}




\begin{tabular}{|c|c|c|c|c|c|c|}
\hline & & & $\begin{array}{l}\text { experie } \\
\text { nce, } \\
\text { and the } \\
\text { type of } \\
\text { job. } \\
\text { The } \\
\text { questio } \\
\text { nnaire } \\
\text { was } \\
\text { used in } \\
\text { data } \\
\text { collecti } \\
\text { on. }\end{array}$ & & & $\begin{array}{l}\text { nt pathway, } \\
\text { clinical } \\
\text { staff } \\
\text { education } \\
\text { in the } \\
\text { prevention } \\
\text { and } \\
\text { manageme } \\
\text { nt of P.I.s. }\end{array}$ \\
\hline $\begin{array}{l}\text { Kielo, E., Suhonen, R., } \\
\text { Salminen, L., \& Scott, M. } \\
\text { (2019). Competence areas for } \\
\text { registered nurses and podiatrists } \\
\text { in chronic wound care, and } \\
\text { their role in wound care } \\
\text { practice. Journal of Clinical } \\
\text { Nursing (John Wiley \& Sons, } \\
\text { Inc.), 28(21/22), 4021-4034. } \\
\text { https://doi.org/10.1111/jocn.149 } \\
\text { 91 }\end{array}$ & $\begin{array}{l}\text { Qualita } \\
\text { tive } \\
\text { design. } \\
\text { Level } \\
\text { II } \\
\text { Grade } \\
\text { A/B }\end{array}$ & $\begin{array}{l}\text { Clinical } \\
\text { staff. } \\
\mathrm{N}=23\end{array}$ & $\begin{array}{l}\text { Semi- } \\
\text { structur } \\
\text { ed } \\
\text { focus } \\
\text { group } \\
\text { intervie } \\
\text { ws } \\
\text { were } \\
\text { used } \\
\text { for data } \\
\text { collecti } \\
\text { on. } \\
\text { Purpos } \\
\text { eful } \\
\text { sampli } \\
\text { ng was } \\
\text { used in } \\
\text { recruiti } \\
\text { ng } \\
\text { particip } \\
\text { ants } \\
\text { from } \\
\text { differe } \\
\text { nt } \\
\text { organiz } \\
\text { ations. } \\
\text { The } \\
\text { data } \\
\text { were } \\
\text { analyze } \\
\text { d with } \\
\text { NVIO }\end{array}$ & $\begin{array}{l}\text { No } \\
\text { theor } \\
\text { etical } \\
\text { found } \\
\text { ation } \\
\text { was } \\
\text { stated }\end{array}$ & $\begin{array}{l}\text { There } \\
\text { was a } \\
\text { differen } \\
\text { ce in } \\
\text { knowle } \\
\text { dge of } \\
\text { how } \\
\text { physici } \\
\text { ans } \\
\text { care for } \\
\text { wounds } \\
\text { from } \\
\text { nurses. }\end{array}$ & $\begin{array}{l}\text { Strong } \\
\text { theoretical } \\
\text { knowledge } \\
\text { of wounds } \\
\text { is needed } \\
\text { for a } \\
\text { clinician to } \\
\text { be able to } \\
\text { develop } \\
\text { skills and } \\
\text { care for } \\
\text { wounds. } \\
\text { The design, } \\
\text { methods, } \\
\text { and } \\
\text { analysis } \\
\text { were seen } \\
\text { as a } \\
\text { limitation } \\
\text { to the } \\
\text { study. } \\
\text { The } \\
\text { authors } \\
\text { recommen } \\
\text { d clinical } \\
\text { staff } \\
\text { wound care } \\
\text { teaching } \\
\text { and } \\
\text { education. }\end{array}$ \\
\hline
\end{tabular}




\begin{tabular}{|c|c|c|c|c|c|c|}
\hline & & & $\begin{array}{l}\mathrm{V} \\
\text { (versio } \\
\text { n 12). }\end{array}$ & & & \\
\hline $\begin{array}{l}\text { McCluskey, P. \& McCarthy, G. } \\
\text { (2017). Nurses' knowledge and } \\
\text { competence in wound } \\
\text { management. Wounds U.K., } \\
\text { 8(2), 37-47. } \\
\text { http://0b30boj34.mp02.y.http.e } \\
\text { ds.b.ebscohost.com.prx- } \\
\text { usa.lirn.net/eds/pdfviewer/pdfvi } \\
\text { ewer?vid=1\&sid=fca5d1c6- } \\
\text { 6695-4460-af28- } \\
\text { bfd06906c515\%40pdc-v- } \\
\text { sessmgr01 }\end{array}$ & $\begin{array}{l}\text { A } \\
\text { quantit } \\
\text { ative, } \\
\text { descrip } \\
\text { tive } \\
\text { study. } \\
\text { Level } \\
\text { IV } \\
\text { Grade } \\
\text { A }\end{array}$ & $\begin{array}{l}\text { Conven } \\
\text { ience } \\
\text { sample } \\
\text { (Nurses } \\
\text { ). } \\
\mathrm{N}= \\
150\end{array}$ & $\begin{array}{l}\text { Resear } \\
\text { cher- } \\
\text { design } \\
\text { questio } \\
\text { nnaires } \\
\text { were } \\
\text { used in } \\
\text { obtaini } \\
\text { ng the } \\
\text { data. } \\
\text { SPSS } \\
\text { was } \\
\text { used in } \\
\text { analyzi } \\
\text { ng the } \\
\text { data. } \\
\text { Data } \\
\text { were } \\
\text { describ } \\
\text { ed, } \\
\text { explain } \\
\text { ed, and } \\
\text { summa } \\
\text { rized } \\
\text { with } \\
\text { the use } \\
\text { of } \\
\text { descrip } \\
\text { tive } \\
\text { and } \\
\text { inferent } \\
\text { ial } \\
\text { statistic } \\
\text { s. } \\
\text { CNS } \\
\text { examin } \\
\text { ed the } \\
\text { questio } \\
\text { nnaire } \\
\text { in } \\
\text { wound } \\
\text { care }\end{array}$ & $\begin{array}{l}\text { No } \\
\text { theor } \\
\text { etical } \\
\text { found } \\
\text { ation } \\
\text { was } \\
\text { stated }\end{array}$ & $\begin{array}{l}\text { Knowle } \\
\text { dge } \\
\text { applicat } \\
\text { ion to } \\
\text { practice } \\
\text { is } \\
\text { enhanc } \\
\text { ed } \\
\text { when } \\
\text { wound } \\
\text { care } \\
\text { knowle } \\
\text { dge is } \\
\text { updated } \\
\text {. }\end{array}$ & $\begin{array}{l}\text { There was } \\
\text { a } \\
\text { substantial } \\
\text { positive } \\
\text { correlation } \\
\text { between } \\
\text { competenc } \\
\text { e and the } \\
\text { number of } \\
\text { wounds } \\
\text { treated by } \\
\text { the nurses } \\
(\mathrm{p}<.001) .\end{array}$ \\
\hline
\end{tabular}




\begin{tabular}{|c|c|c|c|c|c|c|}
\hline & & & $\begin{array}{l}\text { and a } \\
\text { register } \\
\text { ed } \\
\text { nurse. } \\
\text { Ambig } \\
\text { uous } \\
\text { questio } \\
\text { ns were } \\
\text { reconst } \\
\text { ructed } \\
\text { and } \\
\text { clarifie } \\
\text { d. }\end{array}$ & & & \\
\hline $\begin{array}{l}\text { Mwebaza, I., Katende, G., } \\
\text { Groves., S., \& Nankumbi, J. } \\
\text { (2014). Nurse' knowledge, } \\
\text { practices, and barriers in care of } \\
\text { patients with pressure ulcers in } \\
\text { a Ugandan teaching hospital. } \\
\text { Nursing Research and } \\
\text { Practice, 2014. } \\
\text { https://doi.org/10.1155/2014/97 } \\
\underline{3602}\end{array}$ & $\begin{array}{l}\text { A } \\
\text { descrip } \\
\text { tive } \\
\text { cross- } \\
\text { section } \\
\text { al } \\
\text { quantit } \\
\text { ative } \\
\text { study. } \\
\text { Level } \\
\text { II } \\
\text { Grade } \\
\text { B }\end{array}$ & $\begin{array}{l}\text { Nurses } \\
\text { providi } \\
\text { ng } \\
\text { direct } \\
\text { care in } \\
\text { a } \\
\text { selected } \\
\text { unit. } \\
\mathrm{N}=84\end{array}$ & $\begin{array}{l}\text { A } \\
\text { questio } \\
\text { nnaire } \\
\text { and } \\
\text { observa } \\
\text { tional } \\
\text { checkli } \\
\text { st were } \\
\text { used to } \\
\text { obtain } \\
\text { the } \\
\text { inform } \\
\text { ation. } \\
\text { SPSS } \\
\text { (versio } \\
\text { n 16) } \\
\text { was } \\
\text { used in } \\
\text { analyzi } \\
\text { ng the } \\
\text { data. } \\
\text { Descrip } \\
\text { tive } \\
\text { statistic } \\
\text { s were } \\
\text { used to } \\
\text { analyze } \\
\text { the } \\
\text { particip } \\
\text { ants' } \\
\text { demogr } \\
\text { aphics, }\end{array}$ & $\begin{array}{l}\text { No } \\
\text { theor } \\
\text { etical } \\
\text { frame } \\
\text { work } \\
\text { menti } \\
\text { oned }\end{array}$ & $\begin{array}{l}\text { There } \\
\text { was } \\
\text { inadequ } \\
\text { ate } \\
\text { knowle } \\
\text { dge of } \\
\text { the } \\
\text { particip } \\
\text { ants } \\
\text { regardi } \\
\text { ng P.I. } \\
\text { develop } \\
\text { ment, } \\
\text { staging, } \\
\text { and } \\
\text { manage } \\
\text { ment. }\end{array}$ & $\begin{array}{l}\text { Continuous } \\
\text { education } \\
\text { is needed } \\
\text { for clinical } \\
\text { staff to } \\
\text { enable } \\
\text { them to } \\
\text { meet the } \\
\text { wound care } \\
\text { manageme } \\
\text { nt } \\
\text { standards. } \\
\text { A protocol } \\
\text { is required } \\
\text { to assist the } \\
\text { clinical } \\
\text { staff in } \\
\text { recognizin } \\
\text { g, } \\
\text { preventing, } \\
\text { and } \\
\text { managing } \\
\text { the wound. } \\
\text { Nurses } \\
\text { knowing } \\
\text { the } \\
\text { prevention } \\
\text { and } \\
\text { manageme } \\
\text { nt of } \\
\text { wound care } \\
\text { with the }\end{array}$ \\
\hline
\end{tabular}




\begin{tabular}{|c|c|c|c|c|c|c|}
\hline & & & $\begin{array}{l}\text { knowle } \\
\text { dge } \\
\text { level, } \\
\text { and } \\
\text { wound } \\
\text { manage } \\
\text { ment } \\
\text { and } \\
\text { prevent } \\
\text { ion } \\
\text { practic } \\
\text { es. }\end{array}$ & & & $\begin{array}{l}\text { implement } \\
\text { ation of the } \\
\text { wound care } \\
\text { assessment } \\
\text { tool } \\
\text { (Braden) } \\
\text { will help in } \\
\text { wound } \\
\text { manageme } \\
\text { nt. }\end{array}$ \\
\hline $\begin{array}{l}\text { Seo, Y., \& Roh, Y. S. (2020). } \\
\text { Effects of pressure ulcer } \\
\text { prevention training among } \\
\text { nurses in long-term care } \\
\text { hospitals. Nurse Education } \\
\text { Today, 84. } \\
\text { https://doi.org/10.1016/j.nedt.2 } \\
019.104225\end{array}$ & 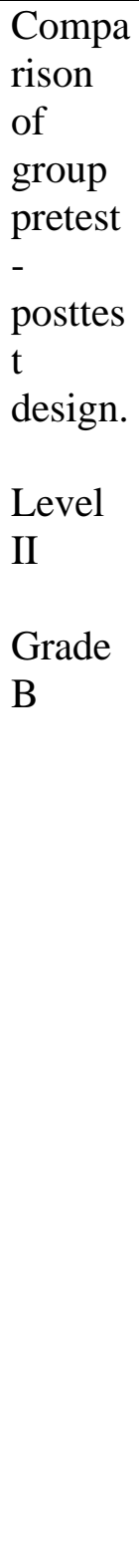 & 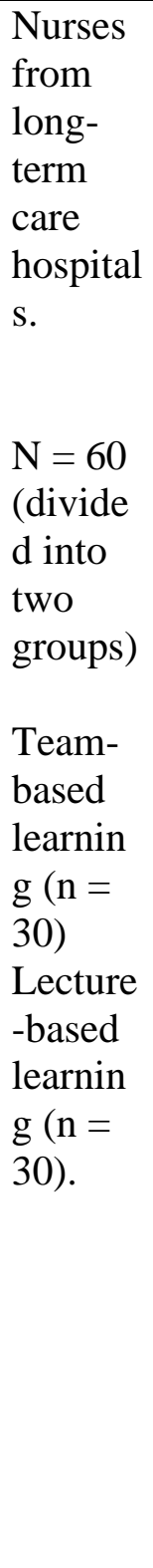 & $\begin{array}{l}\text { There } \\
\text { was } \\
\text { pretest } \\
\text { and } \\
\text { posttest } \\
\text {. } \\
\text { Posttest } \\
\text { was } \\
\text { conduc } \\
\text { ted two } \\
\text { weeks } \\
\text { after } \\
\text { the } \\
\text { pretest } \\
\text { was } \\
\text { conduc } \\
\text { ted for } \\
\text { both } \\
\text { TBL } \\
\text { and } \\
\text { LBL. } \\
\text { Both } \\
\text { groups } \\
\text { showed } \\
\text { improv } \\
\text { ed } \\
\text { knowle } \\
\text { dge } \\
\text { after } \\
\text { the } \\
\text { posttest } \\
\text { (p < } \\
.001 \text {. }\end{array}$ & $\begin{array}{l}\text { No } \\
\text { theor } \\
\text { etical } \\
\text { found } \\
\text { ation } \\
\text { was } \\
\text { stated }\end{array}$ & $\begin{array}{l}\text { It is } \\
\text { essentia } \\
1 \text { to } \\
\text { educate } \\
\text { nurses' } \\
\text { on } \\
\text { pressur } \\
\text { e injury } \\
\text { prevent } \\
\text { ion. }\end{array}$ & $\begin{array}{l}\text { Regardless } \\
\text { of the type } \\
\text { of learning, } \\
\text { it was } \\
\text { concluded } \\
\text { that } \\
\text { pressure } \\
\text { injury } \\
\text { prevention } \\
\text { training is } \\
\text { essential in } \\
\text { enhancing } \\
\text { the nurses' } \\
\text { pressure } \\
\text { ulcer } \\
\text { prevention } \\
\text { knowledge. } \\
\text { Not } \\
\text { examining } \\
\text { the nurses' } \\
\text { educational } \\
\text { needs in } \\
\text { the long- } \\
\text { term care } \\
\text { hospital } \\
\text { was one of } \\
\text { this study's } \\
\text { limitations. } \\
\text { It was also } \\
\text { noted as a } \\
\text { limitation } \\
\text { the }\end{array}$ \\
\hline
\end{tabular}




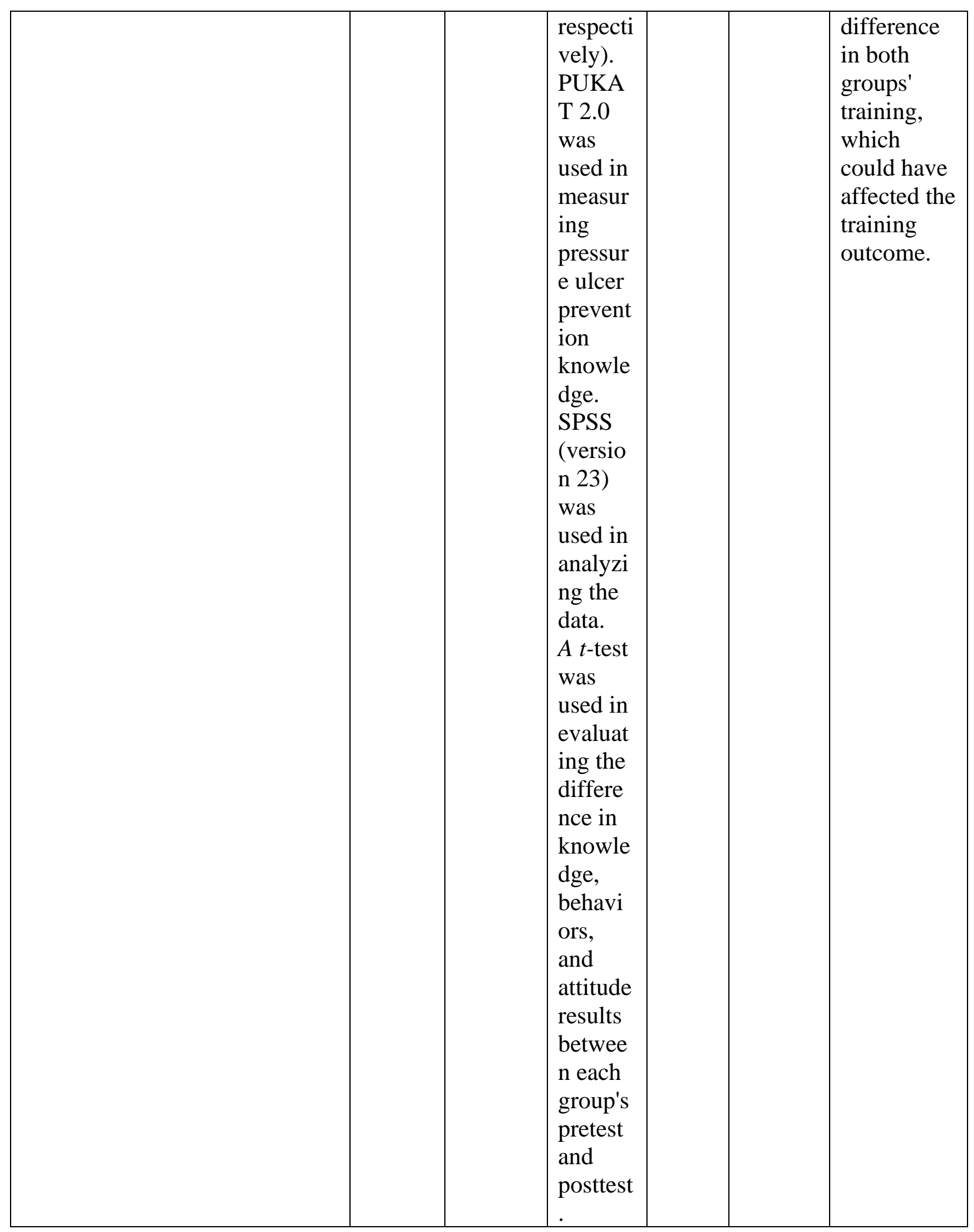


Legend: ANOVA $=$ Analysis of Variance; ANOVA = Analysis of variance; $\mathrm{CNS}=$ Clinical Nurse Specialist; ICD = International Statistical Classification of Disease; NCOD = national Center for Organization Development; LBL = Lecture-Based Learning; PI: Pressure Injury; SCI $=$ Spinal Cord Injury; SPSS $=$ Statistical Package for the Social Sciences; TBL $=$ Team-Based Learning; VEMD = Victoria Emergency Minimum Dataset; 
Appendix E: Summary of Systematic Reviews (S.R.)

\begin{tabular}{|c|c|c|c|c|c|c|c|}
\hline n & $\begin{array}{l}\text { Qual } \\
\text { ity } \\
\text { Gra } \\
\text { de }\end{array}$ & Question & $\begin{array}{l}\text { Search } \\
\text { Strategy }\end{array}$ & $\begin{array}{l}\text { Inclusion/ } \\
\text { Exclusion } \\
\text { Criteria }\end{array}$ & $\begin{array}{l}\text { Data } \\
\text { Extraction } \\
\text { and Analysis }\end{array}$ & Key Findings & $\begin{array}{l}\text { Usefulness/ } \\
\text { Recommen } \\
\text { dation/ } \\
\text { Implication }\end{array}$ \\
\hline 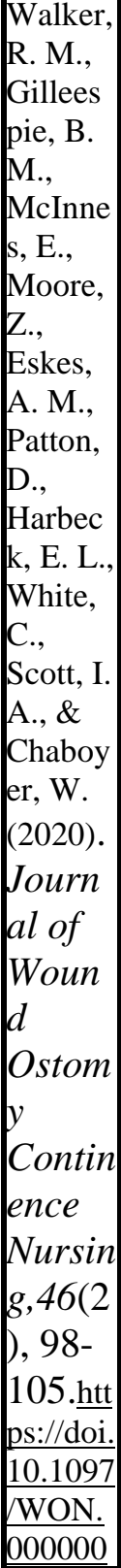 & $\begin{array}{l}\text { Leve } \\
11 \\
\text { Grad } \\
\text { e A }\end{array}$ & $\begin{array}{l}\text { What are the } \\
\text { prevention and } \\
\text { treatment } \\
\text { strategies for } \\
\text { pressure } \\
\text { injuries? }\end{array}$ & \begin{tabular}{|l} 
Only \\
Cochrane \\
reviews were \\
included. \\
Evidence \\
from the \\
articles was \\
screened \\
independently \\
and evaluated \\
by two \\
authors. 163 \\
studies were \\
obtained from \\
the Cochrane \\
database. \\
Titles and \\
abstracts on \\
the wound \\
group website \\
were \\
screened. The \\
terms \\
"pressure \\
injury," or \\
"pressure \\
ulcer" were \\
used as the \\
keywords.
\end{tabular} & $\begin{array}{l}\text { Inclusion: P.I. } \\
\text { prevention and } \\
\text { P.I. treatment. } \\
\text { Excluded: Not } \\
\text { P.I. Intra- } \\
\text { operative, not a } \\
\text { nursing } \\
\text { intervention }\end{array}$ & $\begin{array}{l}\text { Data } \\
\text { dictionary } \\
\text { detailing was } \\
\text { used in } \\
\text { extracting the } \\
\text { data. Two } \\
\text { pairs of } \\
\text { independent } \\
\text { authors } \\
\text { conducted the } \\
\text { data } \\
\text { extraction on } \\
\text { each study. } \\
163 \text { reviews } \\
\text { were screened } \\
\text { but only } 27 \\
\text { reviews were } \\
\text { used. 136 } \\
\text { excluded due } \\
\text { to (a) not } \\
\text { pressure } \\
\text { injuries (n = } \\
100),(b) \\
\text { Intra- } \\
\text { operative (n = } \\
\text { 20), (c) Not a } \\
\text { nursing } \\
\text { intervention } \\
\text { (n=11), (d) } \\
\text { Withdrawn (n } \\
=5 \text { ). }\end{array}$ & $\begin{array}{l}\text { There is clinical } \\
\text { uncertainty of } \\
\text { the nurses in } \\
\text { the prevention } \\
\text { and } \\
\text { management of } \\
\text { wounds. }\end{array}$ & $\begin{array}{l}\text { They } \\
\text { recommende } \\
\text { d the need } \\
\text { for } \\
\text { repositionin } \\
\text { g, surface } \\
\text { support, } \\
\text { health } \\
\text { professional } \\
\text { education, } \\
\text { and nutrition } \\
\text { to prevent } \\
\text { P.I.s. } \\
\text { The meta- } \\
\text { analysis was } \\
\text { limited } \\
\text { because it } \\
\text { favored } \\
\text { reproducible } \\
\text { quantitative } \\
\text { designs. } \\
\text { There was } \\
\text { not enough } \\
\text { clear and } \\
\text { reliable } \\
\text { evidence to } \\
\text { use from the } \\
\text { Cochrane } \\
\text { database. }\end{array}$ \\
\hline
\end{tabular}




\begin{tabular}{|l|l|l|l|l|l|l|l|}
\hline Citatio & Qual & Question & Search & Inclusion/ & Data & Key Findings & Usefulness/ \\
& Gra & & Strategy & Exclusion & Extraction & & Recommen \\
& & & & Criteria & and Analysis & & Implication \\
\hline$\frac{000000}{20}$ & & & & & & & \\
\hline
\end{tabular}

Legend: P.I. = Pressure Injury 
Appendix F: SWOT Analysis

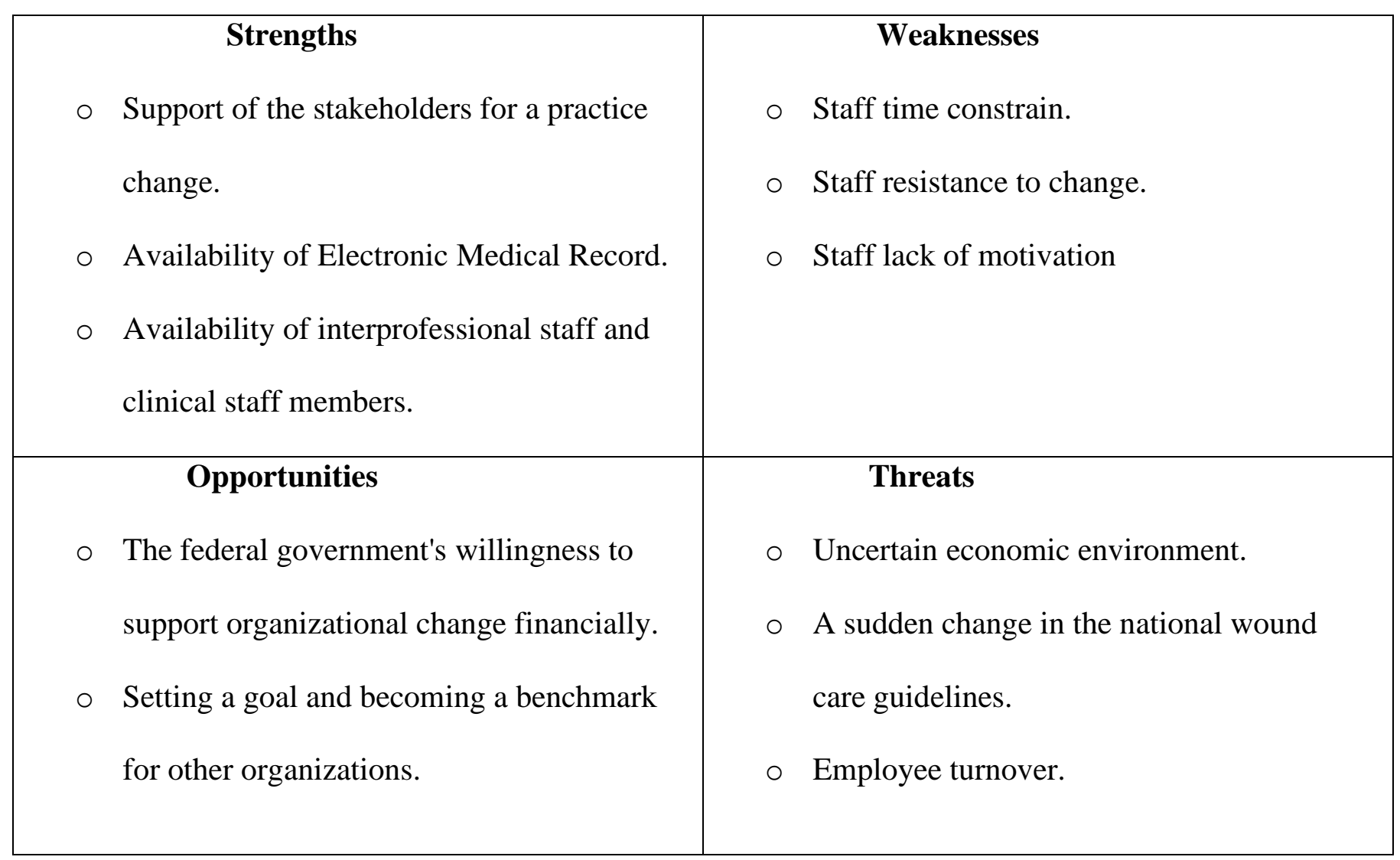


Appendix G: VA Publications Link

www.va.gov/vhapublications/ViewPublication.asp?pub_ID=8274 
Appendix H: Timeline - Steps and Details of the project schedule

\begin{tabular}{|c|c|c|c|}
\hline Task & Responsible Party & Start Time & End Time \\
\hline $\begin{array}{l}\text { Meeting with the } \\
\text { preceptor }\end{array}$ & $\begin{array}{l}\text { Project manager and } \\
\text { the preceptor }\end{array}$ & Week 1 & Week 1 \\
\hline $\begin{array}{l}\text { Discussing with } \\
\text { preceptor regarding } \\
\text { the problem change } \\
\text { project }\end{array}$ & $\begin{array}{l}\text { Project manager and } \\
\text { the preceptor }\end{array}$ & Week 1 & Week 1 \\
\hline $\begin{array}{l}\text { Getting familiar } \\
\text { with the facility }\end{array}$ & Project manager & Week 1 & Week 1 \\
\hline $\begin{array}{l}\text { Faculty approval of } \\
\text { the project }\end{array}$ & $\begin{array}{l}\text { The University of } \\
\text { Saint Augustine } \\
\text { Faculty members }\end{array}$ & Week 2 & Week 6 \\
\hline $\begin{array}{l}\text { Presentation of the } \\
\text { project proposal to } \\
\text { the hospital } \\
\text { executives with an } \\
\text { evidence-based }\end{array}$ & Project manager & Week 6 & Week 7 \\
\hline
\end{tabular}




\begin{tabular}{|c|c|c|c|}
\hline $\begin{array}{l}\text { literature review of } \\
\text { the proposal }\end{array}$ & & & \\
\hline $\begin{array}{l}\text { Facility IRB } \\
\text { approval }\end{array}$ & $\begin{array}{l}\text { Facility IRB } \\
\text { committee }\end{array}$ & Week 7 & Week 8 \\
\hline $\begin{array}{l}\text { Stakeholders' } \\
\text { meeting and } \\
\text { creating awareness } \\
\text { of the importance of } \\
\text { the problem change } \\
\text { project and } \\
\text { formation of the } \\
\text { project team. } \\
\text { Obtaining of } \\
\text { consent. }\end{array}$ & $\begin{array}{l}\text { Project manager, } \\
\text { preceptor, wound } \\
\text { care specialist, } \\
\text { PT/OT, } \\
\text { stakeholders, } \\
\text { dietician }\end{array}$ & Week 9 & Week 9 \\
\hline $\begin{array}{l}\text { Meeting with the } \\
\text { I.T. regarding } \\
\text { electronic medical } \\
\text { record access. } \\
\text { Meeting with the } \\
\text { finance dept to } \\
\text { review the budget } \\
\text { for the project. }\end{array}$ & $\begin{array}{l}\text { Projector Manager, } \\
\text { I.T. department. } \\
\text { Finance dept rep. } \\
\text { hospital executives. } \\
\text { And the project } \\
\text { manager }\end{array}$ & Week 9 & Week 9 \\
\hline
\end{tabular}




\begin{tabular}{|c|c|c|c|}
\hline $\begin{array}{l}\text { Wound care training } \\
\text { for establishment of } \\
\text { policy in progress }\end{array}$ & $\begin{array}{l}\text { Wound care } \\
\text { Educator, with the } \\
\text { project manager } \\
\text { checking in on the } \\
\text { progress. }\end{array}$ & Week 9 & Week 10 \\
\hline $\begin{array}{l}\text { Collection of } \\
\text { attendance } \\
\text { information from } \\
\text { the wound care } \\
\text { educator }\end{array}$ & Project manager & Week 11 & Week 11 \\
\hline $\begin{array}{l}\text { Implementation and } \\
\text { evaluation of the } \\
\text { project change. }\end{array}$ & $\begin{array}{l}\text { Project manager, } \\
\text { project team } \\
\text { members, and } \\
\text { interprofessional } \\
\text { personnel. }\end{array}$ & Week 12 & Week 15 \\
\hline \multicolumn{4}{|l|}{$\begin{array}{l}\text { Term } 3 \\
\text { Nur } 7803\end{array}$} \\
\hline $\begin{array}{l}\text { Implementation and } \\
\text { evaluation of the } \\
\text { project change } \\
\text { Continues. }\end{array}$ & $\begin{array}{l}\text { Project manager, } \\
\text { project team } \\
\text { members, and } \\
\text { interprofessional } \\
\text { personnel. }\end{array}$ & Week 1 & Week 1 \\
\hline
\end{tabular}




\begin{tabular}{|l|l|l|l|}
\hline Implementation of & Project manager & Week 2 & Week 2 \\
measures for the & & & \\
sustainability of the & & & \\
change projects and & & & \\
project closure. & & & \\
\hline
\end{tabular}


Appendix I: Budget

\begin{tabular}{|l|l|l|l|}
\hline \multicolumn{1}{|c|}{ EXPENSES } & & REVENUE & \\
\hline IT personnel \$37 per hour x 16 & $\$ 592$ & Grants from the federal & $\$ 600$ \\
hours & & government & \\
\hline Office supplies & $\$ 300$ & Institutional budget & $\$ 400$ \\
Project Manager (Graduate & $\$ 0$ & support & \\
student) & & & \\
\hline Total Expenses & & & $\$ 108.00$ \\
\hline Net Balance & $\$ 892.00$ & Total Revenue & \\
\hline
\end{tabular}


Appendix J: Data Collection Tools

1. Data Collection Tool: EMR documentation

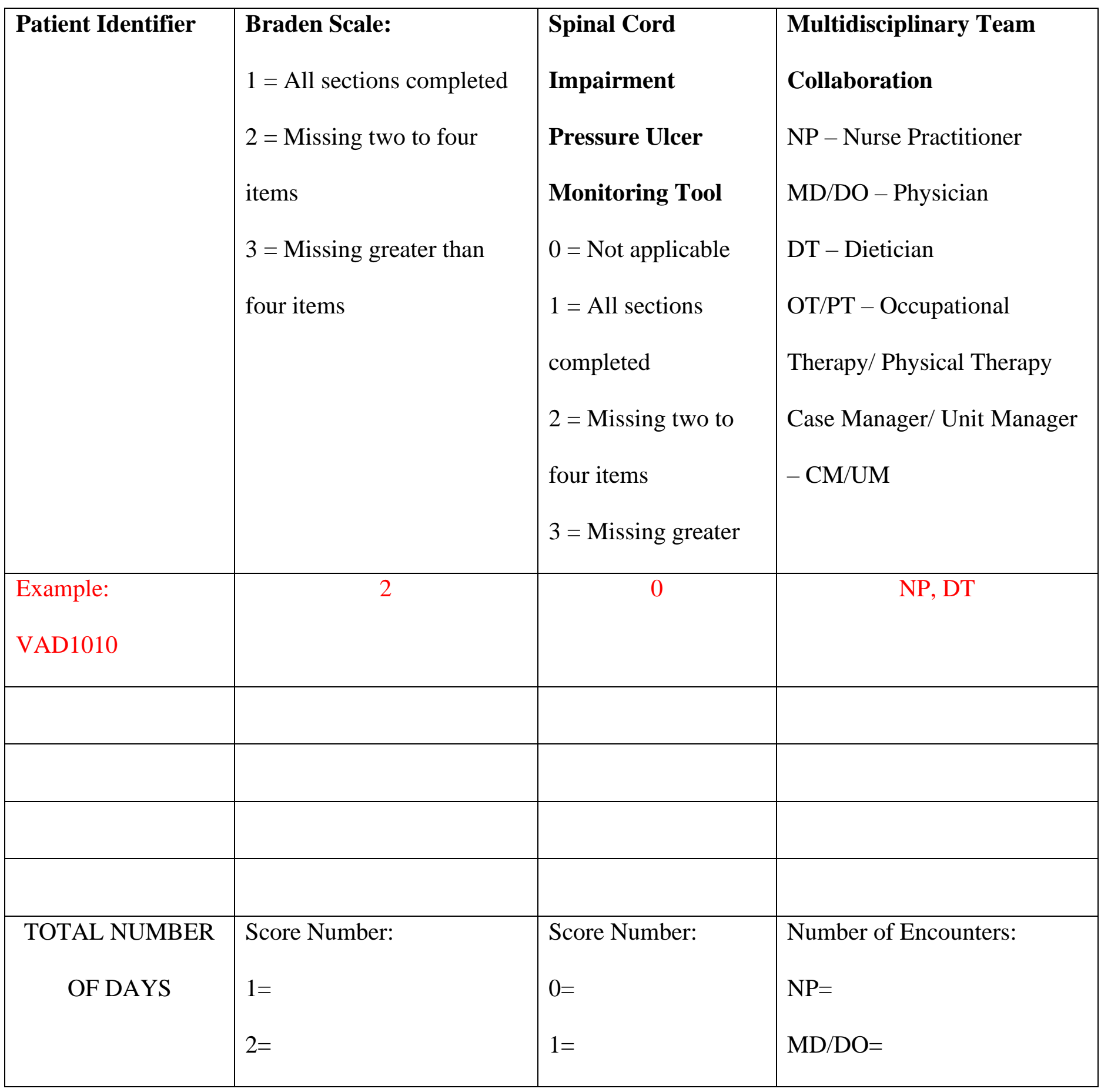




\begin{tabular}{|l|l|l|l|}
\hline & $3=$ & $2=$ & OT/PT $=$ \\
& $3=$ & CM/UM \\
\hline
\end{tabular}


Appendix K: The Braden Scale

BRADEN SCALE FOR PREDICTING PRESSURE SORE RISK

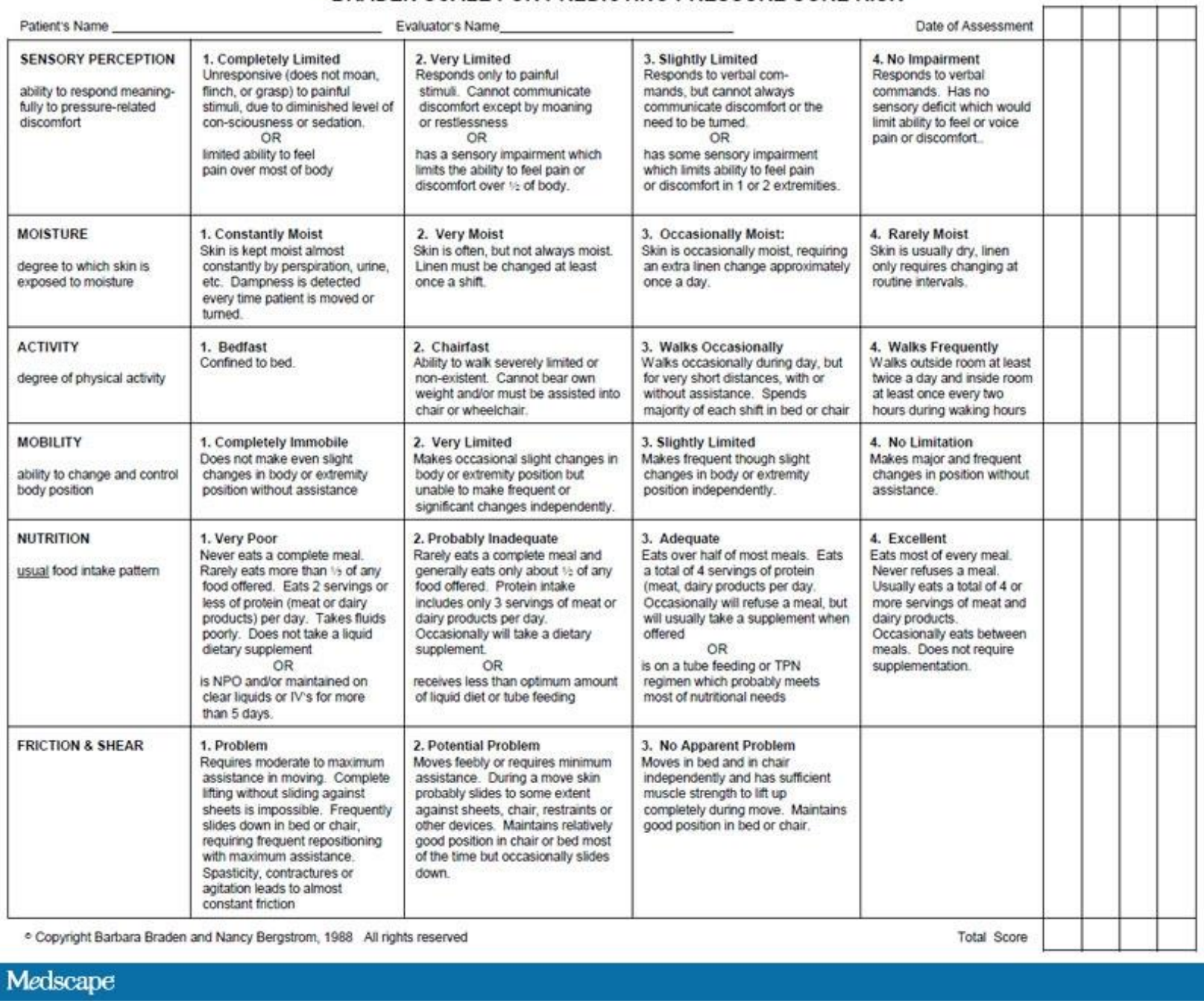

Severe risk: Total score $\leq$ 9, High risk: Total score 10-12,

Moderate risk: Total score 13-14, Mild risk: Total score 15-18.

https://jessbrantnerwvudietetics.files.wordpress.com/2014/01/braden-scale1.jpg 
Appendix L

The Spinal Cord Impairment Pressure Ulcer Monitoring Tool

\section{Spinal Cord Impairment Pressure Ulcer Monitoring Tool}

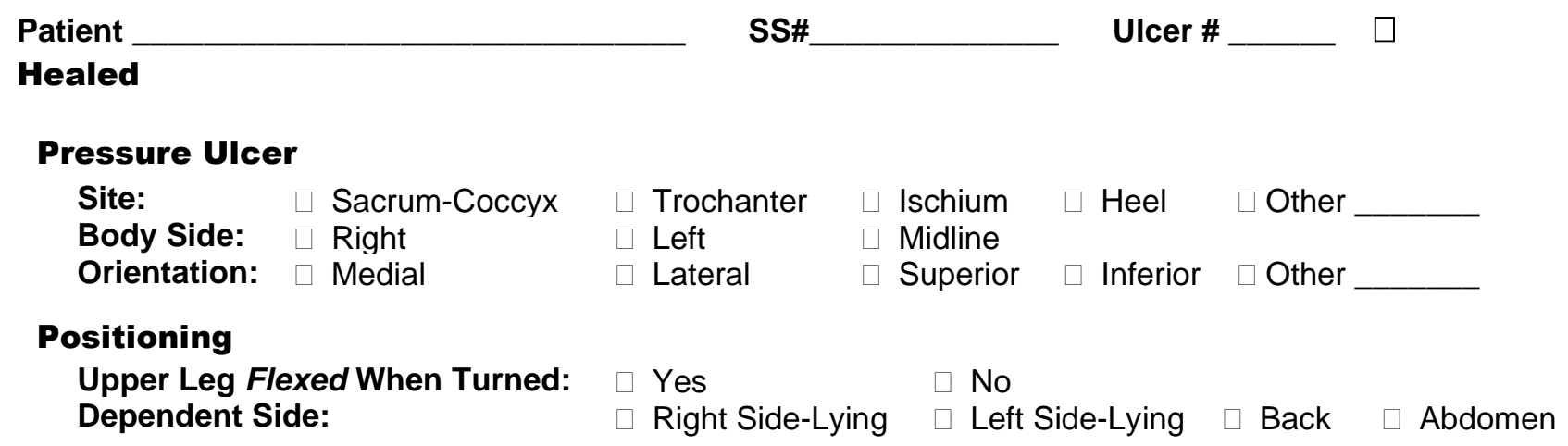

\section{Variables}

\section{GEOMETRIC FACTORS}

$\begin{array}{lcccccc}\text { Surface } & \mathbf{1} & \mathbf{2} & \mathbf{3} & \mathbf{4} & \mathbf{5} & \\ \text { Area } & >0-\leq 1 \mathrm{~cm}^{2} & >1-\leq 2.5 \mathrm{~cm}^{2} & >2.5-\leq 5 \mathrm{~cm}^{2} & >5-\leq 10 \mathrm{~cm}^{2} & >10-\leq 15 \mathrm{~cm}^{2} & \\ \mathbf{( L ~ x ~ W ) ~} & \mathbf{6} & \mathbf{7} & \mathbf{8} & \mathbf{9} & \mathbf{1 0} & \mathbf{L} \mathbf{x} \text {. } \\ & >15-\leq 25 \mathrm{~cm}^{2} & >25-\leq 35 \mathrm{~cm}^{2} & >35-\leq 55 \mathrm{~cm}^{2} & >55-\leq 85 \mathrm{~cm}^{2} & >85 \mathrm{~cm}^{2} & -\mathrm{cm} \times \_ \text {cm }\end{array}$

Do not continue if the Surface Area is " $O$ " indicating complete epithelialization (i.e., resurfacing)

$\begin{array}{ccccccc}\text { Depth } & \mathbf{0} & \mathbf{1} & \mathbf{2} & \mathbf{3} & \mathbf{4} & \text { D } \\ & 0 \mathrm{~cm} & >0-\leq 1 \mathrm{~cm} & >1-\leq 2 \mathrm{~cm} & >2-\leq 3 \mathrm{~cm} & >3 \mathrm{~cm} & \mathrm{~cm}\end{array}$

Edges

1

Not rolled under, thickened, fibrotic, scarred, or hyperkeratotic
2

Rolled under, thickened, fibrotic, scarred, or hyperkeratotic

$\begin{array}{lcccc}\text { Tunneling } & \mathbf{0} & \mathbf{1} & \mathbf{2} & \mathbf{3} \\ & \text { None } & \leq 2 \mathrm{~cm} & >2-\leq 4 \mathrm{~cm} & >4 \mathrm{~cm} \\ \text { Undermining } & \mathbf{0} & \mathbf{1} & \mathbf{2} & \mathbf{3} \\ & \text { None } & \leq 2 \mathrm{~cm} & >2-\leq 4 \mathrm{~cm} & >4 \mathrm{~cm}\end{array}$




$\begin{array}{lccc}\begin{array}{l}\text { Exudate } \\ \text { Type }\end{array} & \begin{array}{c}\mathbf{0} \\ \text { None }\end{array} & \begin{array}{c}\mathbf{1} \\ \text { Serous or } \\ \text { Sanguineous }\end{array} & \begin{array}{c}\text { Green or } \\ \text { Purulent }\end{array} \\ \begin{array}{l}\text { Necrotic } \\ \text { Tissue }\end{array} & \mathbf{0} & \mathbf{1} & \mathbf{2} \\ \text { Amount } & \text { None } & \leq 25 \% & >25 \%\end{array}$

Evaluator:

Date:

Thomason et al. (2016). https://doi. 10.1097/01.ASW.0000482283.85306.8f 